\title{
Productivity and the Services of Capital and Labor
}

THE SLOWDOWN in productivity growth in the U.S. economy that has occurred in the past ten years has been the subject of several careful studies accounting for growth. ${ }^{1}$ Although these studies differ in methodology and emphasis, their overall conclusion is clear. They attribute most of the slowdown in the growth of average labor productivity to a decline in the growth rate of total factor productivity - that is, to developments other than changes in the quantities of capital and labor used in production.

This finding could mean either that the rate of technological change is now much slower than it was, or that the effective flows of capital and labor services have grown more slowly than the measured quantities of

The research upon which this paper is based was funded by a grant from the Alfred P. Sloan Foundation to Brookings for studies in the economics of labor and compensation and by the Office of the Assistant Secretary for Policy Evaluation and Research of the U.S. Department of Labor (contract J-9-M-0-018). Lorin D. Kusmin and Lesley R. Kalmin provided excellent research assistance. I have received many helpful comments from members of the Brookings panel, from colleagues at Brookings, and from Ernst R. Berndt.

1. Edward F. Denison, Accounting for Slower Economic Growth: The United States in the 1970s (Brookings Institution, 1979); Barbara M. Fraumeni and Dale W. Jorgenson, "Capital Formation and U.S. Productivity Growth, 1948-1976," in Ali Dogramaci, ed., Productivity Analysis: A Range of Perspectives (Martinus Nijhoff Publishing, 1981), pp. 49-70; John W. Kendrick, "Productivity Trends in the United States," in Shlomo Maital and Noah M. Meltz, eds., Lagging Productivity Growth: Causes and Remedies (Ballinger, 1980), pp. 9-30; and J. R. Norsworthy, Michael J. Harper, and Kent Kunze, "The Slowdown in Productivity Growth: Analysis of Some Contributing Factors," BPEA, 2:1979, pp. 387-421. 
these inputs, or perhaps both. In this paper I examine the second of these explanations. I suggest that the slowdown in productivity growth has been associated with a decline in the growth of the effective flows of services of capital and labor. Of the two, the decline in the flow of capital services is probably much more important; it has resulted from the increased obsolescence of the capital stock and structural adjustment problems. This paper presents evidence on this central hypothesis explaining the productivity slowdown. However, many questions of measurement and interpretation remain, and many others are raised without complete answers. Further research will be needed to test the hypothesis more fully.

In the first part of the paper the background of the productivity slowdown is briefly reviewed. I then explore the extent to which changes in labor quality or work effort could have led to an overestimate of effective labor services in conventional measures of labor input. The central hypothesis about capital services is subsequently developed. An important empirical fact that suggests a decline in capital services is that the market value of corporate capital has fallen since the mid-1960s. The analytical basis for associating the market value of capital with the flow of capital services is developed in some detail. Finally, the pieces are assembled to see if they add up to an explanation of the slowdown.

\section{The Extent of the Productivity Slowdown}

Table 1 shows the rates of growth of average labor productivity for alternative aggregate sectors and of two estimates of total factor productivity (actually two-factor productivity in both cases).$^{2}$ In the top half of the table the growth rates are calculated from actual data, before any cyclical adjustment. All these unadjusted series show productivity growth slowing, first in 1968-73 and then further in 1973-79. The data also confirm that the two estimates of total factor productivity show a slowdown at least as great as that obtained with the labor productivity measures.

2. Average labor productivity is the ratio of output to labor input computed as the total hours of all workers. Total factor productivity measures the increased output that occurs after allowing for the contribution of labor and capital to output. Here it is computed in a manner described by Denison or Fraumeni and Jorgenson, "Capital Formation." Throughout this paper percentage changes in a variable are calculated as one hundred times the change in the logarithm of the variable. 


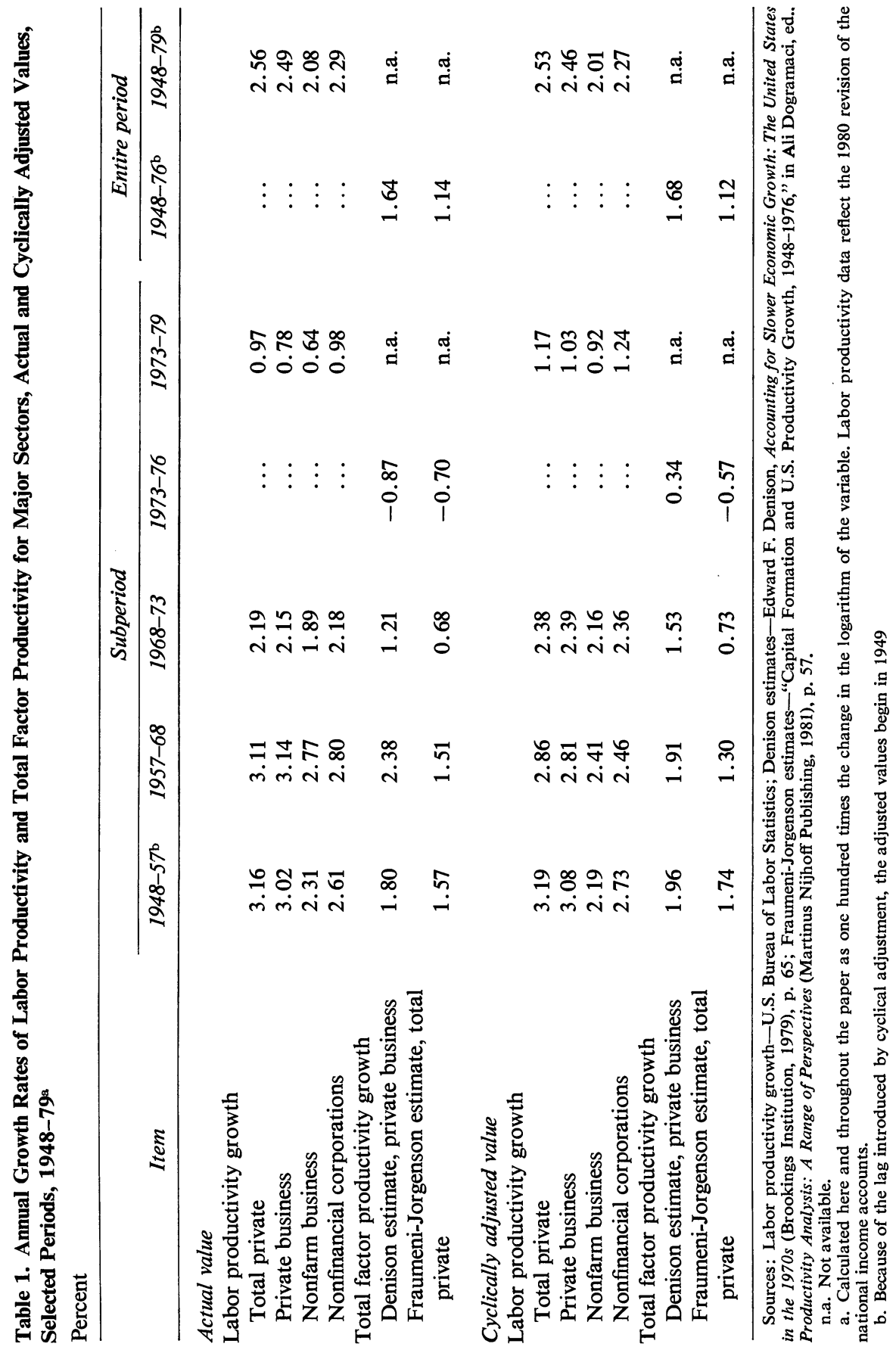


A simple regression procedure was used to derive cyclically adjusted productivity series from the unadjusted data. All the aggregates show roughly constant trend growth rates through 1968, so the logarithm of the level of productivity $(\ln p)$ was regressed on a constant, time $(t)$, and a cyclical indicator $(L U)$ for the 1949-68 period. The regressions for all sectors were similar. For the nonfarm business sector, which is representative, it was the following (with $t$-statistics in parentheses):

$$
\begin{aligned}
& \ln p=1.43+0.0236 t-0.0139 L U \\
& (129.9) \quad(63.3) \quad(-5.96) \\
& +0.000151 L U(-1) \quad \bar{R}^{2}=0.996 . \\
& \quad(0.06)
\end{aligned}
$$

The cyclical variable, $L U$, is the Perry weighted unemployment rate adjusted in two ways. ${ }^{3}$ First, an adjustment was made for the observed lag of unemployment behind the early productivity decline that occurs as demand and output weaken. ${ }^{4}$ A "leading" unemployment rate was constructed for year $t$ as the average Perry rate for the last two quarters of $t$ and the first two quarters of $t+1$. Second, the trend in the unemployment rate was removed. ${ }^{5}$

For all four productivity aggregates, the regression fit very closely through 1968 ( $\bar{R}^{2}$ was 0.99$)$. The trend growth rate of productivity from equation 1 is 2.36 percent a year. It is 2.95 percent for the total private sector, 2.88 percent for private business, and 2.64 percent for nonfinancial corporations. For each sector, the coefficient on $L U$ was always significant and positive. The coefficient on $L U(-1)$ was always insignificant and varied in sign. All equations imply that high unemployment relative to trend reduces the level of productivity.

Cyclically adjusted rates of labor productivity growth are shown in the bottom half of table 1 . They were calculated by applying the coeffi-

3. George L. Perry, "Changing Labor Markets and Inflation," BPEA, 3:1970, pp. $411-41$.

4. For a discussion of this point see Robert J. Gordon, "The 'End-of-Expansion' Phenomenon in Short-Run Productivity Behavior," BPEA, 2:1979, pp. 447-61.

5. This was done to avoid associating the upward drift in unemployment during the 1970s with the slowdown in productivity. The two phenomena may be relatedfor example, if changing demographics both slowed average productivity growth and increased the unemployment rate-but that is a hypothesis to be tested separately. In practice, the trend in the Perry unemployment rate is fairly small and its removal has a rather minor effect on the results. 
cients on the cyclical variables from the equations estimated through 1968 to the entire 1948-79 period. In contrast to the unadjusted series, little slowdown is evident before 1973 in the labor productivity series. In the series for total factor productivity there is evidence of a slowdown starting after 1968. All measures of productivity show a sharp slowdown after 1973 , even when cyclically adjusted.

It is clear that the productivity shortfall is not, to any important extent, a result of cyclical slack. The worsening productivity performance occurred despite a strong expansion from 1976 to 1979 that increased real output in the private business sector 4.5 percent a year. In particular, it is difficult to believe weak productivity resulted from "labor hoarding," the usual explanation of low productivity in a downturn, when total employment in the private business sector was 13.0 percent higher in 1979 than in 1976.

\section{THE MAJOR SECTORS}

A primarily aggregative view of the slowdown is taken in this paper. But to give a more complete review of the facts, table 2 presents the data on labor productivity disaggregated by major sectors of the economy. For the division of nonfarm business into the manufacturing and nonmanufacturing sectors, the 1980 revision of national income accounts are available corresponding to the aggregates in table 1. Evidently labor productivity growth slowed noticeably outside manufacturing after 1968, but this was offset in the aggregate by an acceleration of productivity growth within manufacturing. After 1973 productivity growth declined sharply in both sectors and was close to zero outside manufacturing.

The data disaggregated further by industry have not yet been revised, so the unrevised series are shown for industries in table 2. A comparison of both series for manufacturing shows that the revision increased the recorded productivity growth rate for the $1968-73$ period substantially but did not greatly change it in the other periods.

Among the individual industries, productivity in the construction and mining industries is notable. After increasing in almost every year since 1948 , labor productivity in construction declined by more than 5 percent a year during 1968-73 and continued to fall after 1973, although at a slower rate. If the data are to be believed, average labor productivity in construction by 1979 was at the same level that it was in the early 1950 s. 
Table 2. Annual Growth Rates of Labor Productivity for the Nonfarm Business Sector and for Major Industries, Not Cyclically Adjusted, Selected Periods, 1948-79

Percent

\begin{tabular}{|c|c|c|c|c|c|}
\hline \multirow{2}{*}{$\begin{array}{l}\text { Sector and } \\
\text { industry }\end{array}$} & \multicolumn{4}{|c|}{ Subperiod } & \multirow{2}{*}{$\begin{array}{c}\text { Entire } \\
\text { period, } \\
1948-79\end{array}$} \\
\hline & $1948-57$ & $1957-68$ & $1968-73$ & $1973-79$ & \\
\hline \multicolumn{6}{|l|}{ Nonfarm business ${ }^{\mathrm{a}}$} \\
\hline Manufacturing & 2.64 & 2.82 & 3.52 & 1.51 & 2.63 \\
\hline Nonmanufacturing & 2.14 & 2.76 & 1.04 & 0.25 & 1.82 \\
\hline \multicolumn{6}{|l|}{ Industries $^{\mathrm{b}}$} \\
\hline Manufacturing & 2.57 & 2.84 & 2.72 & 1.41 & 2.47 \\
\hline Agriculture & 5.58 & 4.76 & 5.12 & 2.81 & 4.68 \\
\hline Communications & 4.62 & 5.71 & 4.57 & 6.06 & 5.28 \\
\hline Construction & 2.50 & 2.98 & -5.15 & -2.49 & 0.47 \\
\hline Utilities & 6.78 & 5.16 & 3.19 & -0.66 & 4.18 \\
\hline $\begin{array}{l}\text { Finance, insurance, } \\
\text { and real estate }\end{array}$ & 2.42 & 1.70 & 0.07 & 0.89 & 1.49 \\
\hline Mining & 4.11 & 4.29 & 0.20 & -5.19 & 1.75 \\
\hline Retail trade & 2.36 & 2.63 & 1.70 & 0.78 & 2.04 \\
\hline Wholesale trade & 2.65 & 3.71 & 3.15 & -0.44 & 2.51 \\
\hline Transportation & 2.94 & 3.36 & 2.51 & 0.12 & 2.47 \\
\hline Services & 1.19 & 1.82 & 2.01 & 0.14 & 1.34 \\
\hline
\end{tabular}

Source: Bureau of Labor Statistics.

a. Data reflect the 1980 revision of the national income accounts.

b. The 1980 revision is not yet available by industry, so these data are not directly comparable to other data in this paper.

If construction were excluded from the total private economy, the growth of labor productivity would increase by 0.47 percentage point for the 1968-73 period. For other periods the exclusion of construction makes only a small difference.

The decline of labor productivity in mining in 1973-79 is almost as striking as it is for construction in the previous period. However, because mining is a much smaller industry than construction, its impact on the aggregate series is fairly small. The level of productivity also declined somewhat in two other major industries in the last period.

Although the productivity declines in construction and mining are most striking, it is significant that productivity growth in all the industries except communications slowed after 1968 or after 1973. This suggests that some major common cause is at work. Such a conclusion is reinforced by either a broader or a narrower perspective. Productivity growth has slowed in all the industrial countries. And the U.S. Bureau of Labor Statistics in a study of three- and four-digit industries reports that three- 
Table 3. Annual Growth Rates of the Net and Gross Capital-Labor Ratios, Various Sectors, Selected Periods, 1948-79a

Percent

\begin{tabular}{|c|c|c|c|c|c|}
\hline \multirow[b]{2}{*}{ Item } & \multicolumn{4}{|c|}{ Subperiod } & \multirow{2}{*}{$\begin{array}{c}\text { Entire } \\
\text { period, } \\
1948-7\end{array}$} \\
\hline & $1948-57$ & $1957-68$ & $1968-73$ & $1973-79$ & \\
\hline \multicolumn{6}{|l|}{ Private business } \\
\hline Net & 4.01 & 3.28 & 2.87 & 1.32 & 3.05 \\
\hline Gross & 3.24 & 2.70 & 2.83 & 1.80 & 2.70 \\
\hline \multicolumn{6}{|l|}{ Nonfarm business } \\
\hline Net & 3.20 & 2.91 & 2.69 & 1.09 & 2.60 \\
\hline Gross & 2.38 & 2.31 & 2.64 & 1.61 & 2.25 \\
\hline \multicolumn{6}{|l|}{ Manufacturing } \\
\hline Net & 2.54 & 1.43 & 2.24 & 3.27 & 2.24 \\
\hline Gross & 2.76 & 1.29 & 2.49 & 3.20 & 2.28 \\
\hline \multicolumn{6}{|c|}{ Nonfarm nonmanufacturing } \\
\hline Net & 3.46 & 3.51 & 2.56 & 0.18 & 2.70 \\
\hline Gross & 2.30 & 2.38 & 1.92 & 0.93 & 2.00 \\
\hline \multicolumn{6}{|c|}{ Nonfinancial corporations } \\
\hline Net & 2.73 & 1.32 & 1.65 & 1.32 & 1.78 \\
\hline Gross & 2.01 & 0.87 & 1.59 & 1.68 & 1.47 \\
\hline
\end{tabular}

Sources: The total labor hours are from the Bureau of Labor Statistics; the net and gross capital stock data are from the U.S. Bureau of Economic Analysis.

a. The capital-labor ratios are the ratios of the stock of equipment and structures (net or gross) to total labor hours.

fourths of a sample of seventy-five industries had slower productivity growth after 1973 than before. ${ }^{6}$

\section{CAPITAL-LABOR RATIOS}

Table 3 presents capital-labor ratios for major aggregates for several major sectors. The capital stock measures used are the net and gross stocks of equipment and structures. The gross stock assumes that capital is a one-hoss-shay; it is appropriate if the flow of capital services remains unchanged over the life of the capital. The net stock subtracts depreciation each year and is appropriate if the flow of capital services declines over the lifetime of the capital good in line with measured depreciation.

6. John W. Kendrick, "International Comparisons of Recent Productivity Trends," paper presented at the Electric Power Research Institute Workshop, Palo Alto, January 12-14, 1981; and U.S. Department of Labor, Bureau of Labor Statistics, Productivity Indexes for Selected Industries, 1979 Edition, Bulletin 2054 (U.S. Government Printing Office, 1979), p. 2. 
I have more to say about capital below. But two points are worth noting at the outset. First, there has been a slowdown in the rate of growth of the measured capital-labor ratio in the private business economy, and this has presumably contributed to the slowdown in labor productivity growth. Taken as a whole, however, these data for capital stock do not provide a sufficient explanation for the slowdown, particularly for manufacturing and nonfinancial corporations. Second, the sharp difference in the pattern of capital accumulation between manufacturing and nonmanufacturing within nonfarm business helps to explain the difference in the productivity performance of these two sectors.

\section{Labor Quality and Effort}

I next consider three ways in which the flow of effective labor services may have declined relative to the measured flow of labor input so as to affect productivity growth. First, the influx of young people and women into the labor force may have lowered effective, relative to measured, labor input. Changing educational attainments may also have affected labor quality. Second, the new young entrants to the labor force in some recent years may have been less productive than their counterparts in other years-some "vintages" of workers are less efficient than average. Third, work effort may have fallen for everyone, or at least have fallen on average across the entire range of workers, young and old. Work practices may now include more breaks, more days of sick leave, and more vacation days. These three possibilities are not mutually exclusive, but I examine them separately below to determine how plausible or how important they are likely to be.

\section{DEMOGRAPHIC CHANGES}

The reason most often given for a decline in effective labor services relative to measured labor hours is that the number of young people and women has increased as a percentage of total employment. This argument need have nothing to do with the intrinsic productivity of women compared with men. Women have much lower wage rates than men, and wage rates should measure marginal productivities. It may be that standard practices and conventions confine women to low-productivity jobs. 
In that case, productivity can be improved by making better jobs available to women. Or women may be less productive than men because they have less market experience on average. This same argument applies more forcefully to young people.

Even if one accepts the validity of demographic adjustments in principle, in practice there are some awkward data problems to overcome in making demographic adjustments. George Perry constructed a demographically adjusted measure of labor input for the nonfarm business sector by estimating hours worked by different demographic groups in the sector from the economy-wide data in Current Population Surveys. These were weighted by an estimate of the average relative wages of each group, which he assumed to be fixed through time. ${ }^{7}$ To illustrate the impact of this demographic adjustment, average growth rates for the Bureau of Labor Statistics series (output per hour, the conventional measure) and for the adjusted productivity series (output per effective hour) are shown below for the nonfarm business sector. ${ }^{8}$

Actual values

Output per hour

1950-68 1968-73

1973-79

Output per effective hour

Difference

Cyclically adjusted values

Output per hour

Output per effective hour

The demographic adjustment makes some difference. It reduces labor input growth, thus raising the corresponding productivity growth in all periods, but particularly after 1968 . Comparing 1950-68 with 1968-73, the adjustment would account for a productivity slowdown of 0.15 percentage point a year, or 0.22 point in the cyclically adjusted estimates.

7. George L. Perry, "Labor Force Structure, Potential Output, and Productivity," $B P E A, 3: 1971$, pp. 533-65. Jeffrey M. Perloff and Michael L. Wachter have also considered the importance of demographic adjustment to productivity. See "The Productivity Slowdown: A Labor Problem?" in Federal Reserve Bank of Boston, The Decline in Productivity Growth, Conference Series 22 (FRBB, 1980), pp. 11542.

8. The demographically adjusted series was updated by Thomas C. Hier of Brookings. 
However, comparing the last two periods, the demographic adjustment has comparable effects in each so that it cannot account for any productivity slowdown between those two periods.

\section{EDUCATION}

The growth accounting studies cited in table 1 used a measure of labor input that is adjusted for labor quality. But, for example, Denison's laborquality index has been rising fairly rapidly since 1968, not falling. This is because he adjusts for years of schooling as well as for demographic changes. The logic of wage-weighting that justified the demographic adjustment also suggests an adjustment for education.

Hypotheses about declining labor quality, therefore, do have to confront the trend of rising education level. To argue that quality has declined, one has to show that additional education has not contributed much to the real productivity of workers. If Michael Spence is correct and people acquire years of schooling in order to signal their ability, ${ }^{9}$ substantial increases in the average level of education will not add to overall productivity and may even reduce the efficiency of the labor market in assigning people to jobs. Even if Spence is only partly correct, there is reason to think that the marginal product of additional education (at least in its ability to produce measured output) is low. Richard Freeman has found that the average return to education has been falling, and J. P. Smith and Finis Welch have argued that the overcrowding of the babyboom generation has contributed. ${ }^{10}$ Education is heavily subsidized and is often acquired as a consumption good. The market test for human capital investment is not equivalent to the market test for physical capital. In contrast to the improvements in average education in earlier years, it seems unlikely that the further increases of recent years have been important. People streaming through community colleges and law schools may not be gaining as much human capital as the added years of education imply based on historical evidence. In any case, to contribute to

9. Michael Spence, "Job Market Signaling," Quarterly Journal of Economics, vol. 87 (August 1973), pp. 355-74.

10. R. B. Freeman, The Overeducated American (Academic Press, 1976); and James P. Smith and Finis R. Welch, The Overeducated American? A Review Article, P-6253 (Santa Monica, Calif.: Rand Corp., November 1978). 
speeding the productivity trend, gains in education attainment would have to have speeded up, and this seems especially dubious.

\section{COHORT-SPECIFIC CHANGES IN THE QUALITY OF LABOR}

The evidence cited most often to indicate a decline in the labor quality of younger cohorts is the downward trend in Scholastic Aptitude Test (SAT) scores. These scores have been declining since 1963 after showing a slight upward trend for some years. The cohort of students born in 1945 achieved an average of 478 on the verbal part of the test and 502 on the mathematical part when their scores were recorded in 1963. This compares with students born in 1962 who averaged 424 on the verbal and 466 on the mathematical parts. These raw figures overstate the amount of quality change, however, because there was a considerable increase in the proportion of high school students taking the test. This apparently explains about half of the decline in scores overall, and nearly all the decline before $1973 .{ }^{11}$

Whatever the significance of these changes, SAT scores are not a sufficiently reliable measure of cohort labor quality to be used in making a direct adjustment of the data on labor hours. Rather than attempting such a direct adjustment, the cohort-quality hypothesis is explored by means of a simple simulation experiment. It is assumed that there are vintages of labor, with individuals categorized by year of birth. The cohort of people born in year $\tau$ will display individual differences within their cohort, but as those people grow up they will have certain experiences in common that affect labor productivity-including the quality of schools attended, social attitudes toward work, or the influence of television.

One hour of work supplied by a person born in the year $\tau$ is modeled as $v_{\tau}$ hours of effective labor input, where $v_{\tau}$ can be greater or less than unity. ${ }^{12}$ The vintage factor $v_{\tau}$ is assumed to remain constant over each person's working life.

If $N_{\tau t}$ is the number of labor hours supplied in year $t$ by persons of

11. Landon Y. Jones, "The Mystery of the Declining SAT Scores," Princeton Alumni Weekly (October 20, 1980), pp. 23-27.

12. This specification assumes that variations in labor quality can be made equivalent to variations in the quantity of labor. 
vintage $\tau$, and if $L_{t}^{E}$ is the total effective labor hours supplied in $t$ by all workers, then

$$
L_{t}^{E}=\sum_{\tau} N_{\tau t} v_{\tau}
$$

where the summation extends between the oldest and youngest vintages active in year $t$. The total labor input supplied in year $t$, without adjustment for cohort quality, is simply $L_{t}=\sum N_{\tau t}$, so that an index of overall labor quality in $t$ can be defined from

$$
\frac{L^{E}}{L}=\frac{\sum_{\tau} N_{\tau t} \nu_{\tau}}{\sum_{\tau} N_{\tau t}}=\sum_{\tau} \theta_{\tau t} \nu_{\tau},
$$

where the summations are taken as described above. The ratio of effective labor input to actual labor input, which is the index of labor quality, is the weighted average of the quality indexes of all the cohorts currently employed, where the weights, $\theta_{\tau t}$, are the fractions of total hours supplied by each cohort.

To determine whether plausible variations in $v_{\tau}$ could account for much of the productivity slowdown, a simulation was conducted in which one-half of the fluctuations of labor productivity in the private sector around its trend (after cyclical adjustment) was attributed to variations in labor quality, $L^{E} / L$. The resulting series for labor quality is shown in table $4 .{ }^{13}$ The series remains fairly close to unity until 1968 and then drops to 0.93 by 1979 - corresponding to the fairly stable productivity trend until 1968 and the slowdown thereafter.

To estimate the path of $v_{\tau}$ that would generate the hypothesized path of overall labor quality, it is assumed that $v_{\tau}$ can be expressed as an arbitrary fourth-order polynomial in $\tau$. The parameters of the polynomial are then estimated after substituting back into equation 3 . The last column of table 4 gives the resulting estimated values of $v_{\tau}$, showing how successive generations (identified by their year of birth) must have varied in their cohort quality, if these variations were responsible for the pattern of overall labor quality assumed in the first column. ${ }^{14}$

13. The actual specification used was $\ln \left(L^{E} / L\right)=0.5(\ln p-\ln \hat{p})$, where $\ln p$ and $\widehat{\ln p}$ are the actual and fitted values from equation 1 for the total private economy. The trend and cyclical coefficients are applied to the entire 1949-79 period.

14. Persons born well before 1933 were in the labor force in 1949, and the estimated parameters of the polynomial take this into account. But the estimated cohortquality index remains close to unity before 1933, so earlier years have been omitted from the table. 
Table 4. Change in Cohort-Specific Labor Quality Consistent with Half the Productivity Shortfall, 1949-79

\begin{tabular}{|c|c|c|c|}
\hline Year & $\begin{array}{c}\text { Assumed overall } \\
\text { labor quality index }\end{array}$ & Year of birth & $\begin{array}{l}\text { Implied cohort- } \\
\text { quality index }\end{array}$ \\
\hline 1949 & 0.992 & 1933 & 0.992 \\
\hline 1950 & 1.000 & 1934 & 0.996 \\
\hline 1951 & 0.998 & 1935 & 1.000 \\
\hline 1952 & 0.999 & 1936 & 1.003 \\
\hline 1953 & 1.007 & 1937 & 1.007 \\
\hline 1954 & 1.006 & 1938 & 1.010 \\
\hline 1955 & 1.004 & 1939 & 1.013 \\
\hline 1956 & 0.995 & 1940 & 1.015 \\
\hline 1957 & 1.002 & 1941 & 1.016 \\
\hline 1958 & 1.005 & 1942 & 1.017 \\
\hline 1959 & 0.994 & 1943 & 1.016 \\
\hline 1960 & 0.999 & 1944 & 1.015 \\
\hline 1961 & 0.998 & 1945 & 1.012 \\
\hline 1962 & 1.000 & 1946 & 1.008 \\
\hline 1963 & 1.001 & 1947 & 1.001 \\
\hline 1964 & 1.004 & 1948 & 0.994 \\
\hline 1965 & 1.002 & 1949 & 0.984 \\
\hline 1966 & 1.001 & 1950 & 0.971 \\
\hline 1967 & 0.997 & 1951 & 0.957 \\
\hline 1968 & 0.996 & 1952 & 0.939 \\
\hline 1969 & 0.986 & 1953 & 0.919 \\
\hline 1970 & 0.984 & 1954 & 0.896 \\
\hline 1971 & 0.987 & 1955 & 0.869 \\
\hline 1972 & 0.985 & 1956 & 0.838 \\
\hline 1973 & 0.982 & 1957 & 0.804 \\
\hline 1974 & 0.969 & 1958 & 0.765 \\
\hline 1975 & 0.969 & 1959 & 0.722 \\
\hline 1976 & 0.967 & 1960 & 0.674 \\
\hline 1977 & 0.958 & 1961 & 0.621 \\
\hline 1978 & 0.942 & 1962 & 0.563 \\
\hline 1979 & 0.931 & 1963 & 0.499 \\
\hline
\end{tabular}

Source: Calculations by the author based on data from the Bureau of Labor Statistics. See the text for an explanation of the labor- and cohort-quality indexes.

The decline in the labor quality of the cohort would have to have been very sharp indeed-from an index of about 1.0 for those born in the 1940 s to about 0.5 for those born in the early 1960s. In my view, such a sharp decline is implausible and of a much larger magnitude than anything implied by the SAT scores or related evidence, which suggests that the cohort-quality hypothesis can at most explain a small fraction of the slowdown.

To combine the demographic and cohort-quality hypotheses, a simu- 
lation was conducted using an overall labor quality series derived from the nonfarm business sector, with productivity adjusted for both cyclical and demographic factors. Because demographics explain some slowing of the productivity trend, the overall labor quality series dropped only to 0.96 percent by 1979 , rather than to 0.93 percent as reported in table 4 . But the cohort-quality series dropped almost to 0.5 because most of the decrease in overall quality came in the last few years of the 1970s, implying a sharp deterioration in vintage quality at that time.

The demographic adjustment hypothesis and the cohort-quality hypothesis differ sharply in their predictions for future productivity. The former predicts that productivity growth will improve as young workers and women acquire experience and age; the latter, a disastrous future for productivity - unless cohort quality improves sharply—as the low-quality younger workers become an increasingly important part of the total effective hours supplied by the work force.

\section{HOURS SPENT WORKING}

Official measures of labor input and productivity are based on the number of hours for which workers are paid. Other things being equal, a 1 percent reduction in hours actually worked relative to hours paid will reduce measured labor productivity by 1 percent. There are two different questions concerning this discrepancy. First, how much time are people actively working during the hours when they are actually at their place of work? Second, how much time is paid for but not spent at work because of holidays, vacations, and sick leave?

Frank Stafford and Greg Duncan have presented some findings on the first question, based upon time diaries completed by a sample of several hundred working men and women in the mid-1970s. ${ }^{15}$ They found that the average worker spends a considerable amount of time at work but not working. But because only one year of data are available, it is hard to say whether this phenomenon has increased or decreased, let alone whether it has accelerated. One suspects that the average worker has always taken a fair amount of slack time.

There is more information on the second question, although still not

15. Frank Stafford and Greg J. Duncan, "The Use of Time and Technology by Households in the United States," Working Paper Series (University of Michigan, Institute for Social Research, June 1979). 
the full time-series that would be necessary to make a definitive statement about breaks in trend. The Bureau of Labor Statistics surveyed about 3,200 establishments periodically from 1966 to 1977 and determined the relation between work hours and hours of paid leave. ${ }^{16}$ These surveys indicate that the gap between hours at work and hours paid has been widening slowly and fairly steadily during the course of the surveys. The average rate of decline of hours at work relative to hours paid over the eleven-year period was 0.16 percent a year, with the gap reaching 7.6 percent by 1977 . This decline helps determine the measured productivity trend; but without a break in the rate of decline, it cannot account for any change in the trend. ${ }^{17}$

\section{SUMMARY OF LABOR INPUT}

Considering the three hypotheses about labor services togetherdemographics, cohort-specific quality change, and time on the job-it appears that the growth of effective labor services has slowed a little relative to the growth of measured total labor hours. Weighing the evidence subjectively, a decline in labor services relative to measured labor input accounted for a slowdown of perhaps 0.30 percentage point in the measured rate of labor productivity growth since 1968 in the total private economy, with demographic changes accounting for most of this decline. $^{18}$

\section{Capital Stock and Capital Services}

Trends in capital-labor ratios for several sectors are shown in table 3 above. The growth rate of the capital-labor ratio in the broad aggregates has slowed, and there is no reason to doubt that this has contributed to

16. U.S. Bureau of Labor Statistics, Employee Compensation in the Private Nonfarm Economy, 1977, Summary 80-5 (BLS, April 1980).

17. Stafford and Duncan also address the question of the decline in hours at work relative to hours paid and find a larger decline from 1965 and 1975 than that shown in the Bureau of Labor Statistics data. However, the authors' estimates are based on a rather small sample.

18. The effect on subsectors may be uneven. Employment in manufacturing may not have experienced the same demographic changes as the economy as a whole. 
the slowing of the growth rate of labor productivity. In the private business sector, if the contribution of capital to production is given by its 25 percent share of income, the decline in the growth rate of the capitallabor ratio after 1968 could account for a decrease in labor productivity growth of 0.39 percentage point a year. Furthermore, the different pattern of growth in the capital-labor ratio in manufacturing helps explain why productivity in that sector has behaved differently from productivity measured for the other broad aggregates.

Beyond these observations, however, it becomes difficult to explain the slowdown of labor productivity based upon the standard capital-labor ratios. The ratios grew more slowly in 1957-68 than in 1948-57 for most sectors in table 3, but there is no corresponding decline in the growth of labor productivity. In manufacturing and the nonfinancial corporate business sectors the growth rates of the capital-labor ratio after 1957 show no relation or a perverse relation to labor productivity growth.

The growth accounting studies of Denison and Fraumeni-Jorgenson also imply little importance for capital in explaining the productivity slowdown. Both studies use more comprehensive definitions of capital than table 3 and analyze a broad output measure. As table 1 shows, both studies reveal sharp slowdowns in the growth of total factor productivity, a concept that already takes account of the growth in capital, and thus they identify a slowdown that is independent of the capital stock.

The limited ability of the capital-labor ratio to explain medium-term productivity trends is puzzling. If a cross section of countries is compared, a fairly strong correlation exists between the growth of capital and that of productivity. ${ }^{19}$ Cross-section analyses of data on U.S. industries and firms also reveal such a relation. But something seems to happen over time to disturb that relation. If the flow of capital services changes relative to the stock of capital, the change could explain the puzzle, and this is the argument I make below. ${ }^{20}$

19. Laurits R. Christensen, Diane Cummings, and Dale W. Jorgenson, "Relative Productivity Levels, 1947-1973: An International Comparison," paper presented at the International Seminar on Macroeconomics at Oxford, June 22-24, 1980; and Kendrick, "International Comparisons of Recent Productivity Trends."

20. In a previous paper I have argued in terms of mismeasurement of capital rather than in terms of the flow of capital services relative to the measured stock. I am grateful to Ernst Berndt for helpful conversations on this point. See Martin N. Baily, "The Productivity Growth Slowdown and Capital Accumulation," American Economic Review, vol. 71 (May 1981, Papers and Proceedings, 1980), pp. 326-31. 


\section{STRUCTURAL CHANGE AND CAPITAL SERVICES}

What enters the production function is not the stock of capital but the flow of capital services, and substantial changes can take place in the flow of services from a given plant. A plant can operate three shifts seven days a week, or eight hours a day for five days. It can be on short time or be closed temporarily. It can be scrapped because of obsolescence even though it has not worn out and still appears in statistical measures of the capital stock.

Previous studies have addressed some of these issues surrounding the measurement of capital services. Some have measured labor input by fulltime equivalent workers rather than total hours, based on the hypothesis that this more accurately reflects the hours worked by capital. Some part of the cyclical correction of productivity can also be viewed as an attempt to adjust for changes in capital services that come from variations in the utilization rate. And finally, the debate about the relative merits of the gross and net capital stock is really about which concept better approximates the flow of capital services. ${ }^{21}$

These adjustments to the capital stock may be in the right direction, but they do not go far enough. As Martin Feldstein and Michael Rothschild have stressed, depreciation and scrapping are primarily economically determined and are only partially parameters of physical decay. ${ }^{22}$ A factory that is scrapped, extensively modified, or is put on reduced hours of operation has probably not worn out; it has become uneconomic. Individual components need replacement, and certainly maintenance custs rise over time. But obsolescence is usually more important in determining economic value. The standard data on capital stock take no account of variations in scrapping rates, utilization rates, or the extent to which capital spending is used to modify old plants because of changes in factor price or in product mix.

But if the slowdown in productivity growth is to be explained by a decline in capital services, it is necessary to do more than point out that it could have happened. One wants to know that it did happen and why.

21. See the paper by Norsworthy and others, "The Slowdown," and the comment on that paper by Denison.

22. Martin S. Feldstein and Michael Rothschild, "Towards an Economic Theory of Replacement Investment," Econometrica, vol. 42 (May 1974), pp. 393-423. 
I argue that market valuation offers evidence that it did happen. On the question of why, I contend that major structural changes have taken place that have rendered old capital obsolete. The past fifteen years have been a period of considerable turmoil for the U.S. economy, and indeed for much of the world economy. When major changes in factor price or in product price occur and technology choice is embodied in the capital stock, structural change causes capital obsolescence and a decline in capital services. The rise in the price of energy after 1973 had some of these consequences, and I turn to it next.

Energy. Many have attributed the productivity slowdown to the rise in the price of energy, one of the most dramatic of the structural changes of the 1970s. Energy prices started to edge up in the late 1960s and then jumped in 1973 and again in 1979; thus the timing is right. The energy crisis is a worldwide phenomenon and so is the productivity slowdown.

Edward Hudson and Dale Jorgenson and Ernst Berndt and David Wood have advanced the hypothesis that capital, which is energy-using, has become more expensive relative to labor as a result of the energy crisis, and this has led to a substitution of labor for capital. ${ }^{23}$ The importance of this mechanism was questioned because the growth in the capitallabor ratio had not slowed by enough to explain much of the productivity slowdown. But if the hypothesis of the present paper is correct and capital services have declined relative to the measured capital stock, capitalenergy interactions need to be reexamined.

Efforts to save energy will reduce capital services. Energy-inefficient vintages of capital will be utilized less intensively and scrapped earlier following a rise in energy prices. ${ }^{24}$ Moreover, some part of capital spending will be devoted to improving energy efficiency rather than to deepening capital, although it will still be recorded as an addition to the capital

23. Ernst R. Berndt and David O. Wood, "Engineering and Econometric Interpretations of Energy Capital Complementarity," American Economic Review, vol. 69 (June 1979), pp. 342-54. Edward A. Hudson and Dale W. Jorgenson, "Energy Prices and the U.S. Economy, 1972-1976," Natural Resources Journal, vol. 18 (October 1978), pp. 877-97.

24. The example of automobiles suggests that variation in the use intensity may be more important than scrapping. Households are driving less (or are driving energy-inefficient cars less) but not scrapping earlier. The automobile story is complicated, however, by the fact that marginal vintage automobiles (1970-73) are substantially more fuel-efficient than the subsequent vintage (1974-75). 
stock. Thus the ability of a given measured capital stock to produce measured output is reduced.

Higher energy prices will also cause shifts in product demand that cannot be met by conversion and that result in "structural unemployment" of the capital stock in some sectors and capital shortages in others. For example, there has been a dramatic reduction in the growth of demand for electricity. Because decisions regarding capital purchase are made years in advance in the electric generating industry, persistent excess capacity has resulted. This product-specific capital cannot be used elsewhere. Other shifts in the product mix, due to causes besides energy prices, create the same problem.

Higher energy prices also make capital obsolete by changing the nature of the products. Producers of energy-using products will redesign them to be more energy-efficient and convert their capital stock to produce new types of product. The most familiar example is the automobile industry, in which the shift of demand from large cars and large engines has caused a major restructuring of the industry and its capital stock. Aircraft, machine tools, appliances, and construction are all sectors that have energy-using durable goods as their output.

Quantitative Impact of Energy. Based upon the 1973-76 period, George Perry suggested that energy could not have been a major cause of the productivity slowdown because the cost of energy is not a sufficiently large fraction of GNP and not enough energy had been saved to justify the sacrifice of output implied by the productivity slowdown. ${ }^{25}$ That argument requires two amendments, one conceptual and one to bring the facts up to date. To the extent that investment is devoted to energy saving rather than to conventional purposes that expand output and productivity, the capital stock will overstate the output that can be produced. However, the timing between output lost and energy saved need not coincide. When investment is redirected to energy conservation, the discounted value of forgone output should not exceed the discounted value of energy saved, ignoring possible differences in uncertainty between the two alternatives. But if energy savings are expected to continue for a longer time than the

25. George L. Perry, "Potential Output: Recent Issues and Present Trends," in Center for the Study of American Business, U.S. Productive Capacity: Estimating the Utilization Gap, Working Paper 23 (CSAB, Washington University, St. Louis, 1977), pp. 1-20 (Brookings Reprint 336, 1978). 
forgone output that is sacrificed, in the early years the output lost may exceed the energy saved. If energy-saving investment takes place at the expense of investment in short-lived equipment, for instance, there will be a presumption that the two time-streams differed in this way.

The argument applies to investment for producing energy-efficient products as well as to investment that conserves energy in the production process itself. Energy will be saved using the efficient product over its entire lifetime. The discounted value of these savings justifies a higher product price (in general not measured as a quality improvement and hence not counted as higher output) which, in turn, justifies investment in producing the more efficient product. Again, the capital stock overstates the measured output that can be produced. What is more, compared with investing to save energy in the production process, energy savings over the product's lifetime further stretches the time during which those savings occur relative to the time during which output is forgone by sacrificing the alternative-conventional investment.

As of 1979, energy conservation in the United States had become substantial, as shown below.

Total energy consumed

Residential and commercial

Industrial

Transportation
Energy consumption by end-use sector (quads per year)

\begin{tabular}{rrrr}
\hline 1948 & 1968 & 1973 & 1979 \\
32.96 & 61.32 & 74.61 & 78.95 \\
9.16 & 21.09 & 27.40 & 29.32 \\
14.73 & 24.70 & 29.69 & 29.84 \\
9.07 & 15.53 & 18.53 & 19.79
\end{tabular}

Between 1948 and 1968, energy use increased by 3.10 percent a year while GNP grew by 3.85 percent a year. This trend of rising energy productivity was then broken from 1968 to 1973 , when energy use increased by 3.92 percent a year, while GNP rose by 3.41 percent a year. From 1973 to 1979 , the use of energy went up at a rate of 0.94 percent a year, while GNP rose by 2.78 percent a year. It is hard to say precisely what energy-productivity trends would have been. But, most likely, energy consumption was down between 10 and 15 percent, or 8 to 10 quads a year, by 1979, depending upon whether one projects that, in the absence of the price rise, the energy-GNP ratio would have stayed the same or risen as it had in the previous five years. The breakdown by sector shown in the data above does not distinguish business, household, and govern- 
ment consumption in residential and commercial or in transportation uses. But there has been essentially zero growth of energy consumption in the industrial sector since 1973, which suggests the business sector is doing its share of energy saving.

Perry estimated that energy use was down 3 to 5 percent relative to trend by 1976 and that this might account for 0.2 percentage point in annual productivity growth between 1973 and $1976 .{ }^{26}$ Because energy use had fallen 10 to 15 percent below trend by 1979 , up to 0.4 percentage point a year of productivity slowdown between 1976 and 1979 may be accounted for by his type of calculation. If the output loss in these years exceeds the value of energy savings because of the timing differences discussed above, the output and productivity losses may have been even greater. This paper does not argue that the energy crisis has been the only cause of the decline in capital services and hence productivity; other adjustment problems have also been important. But the reasoning presented here shows that energy saving could account for a noticeable part of the productivity slowdown.

Foreign Trade. Another important source of changing production in the U.S. economy has come from foreign trade. Table 5 shows how the economy has become increasingly involved in world trade since World War II, particularly in the past fifteen years. During this period both exports and imports of merchandise have risen sharply relative to total goods output. Exports and imports (excluding petroleum) totaled 31.1 percent of goods output by 1979 , more than double the 1968 share. $^{27}$

On balance, the United States is not being overwhelmed by foreign competition. Once the overvalued dollar was devalued, exports grew rapidly. The overall trade balance remains positive today if the huge increase in petroleum imports is excluded. But the big increase in total trade has meant shifting resources and has brought adjustment problems in specific industries.

Between 1968 and 1978 net exports of agricultural goods climbed from $\$ 230$ million to $\$ 13.26$ billion; net exports of chemicals increased from $\$ 2.04$ billion to $\$ 6.60$ billion; net exports of capital goods rose from

26. Ibid., pp. 10, 12.

27. For a discussion of the change in the role of trade in the U.S. economy, see William H. Branson, "Trends in United States International Trade and Investment since World War II," in Martin Feldstein, ed., The American Economy in Transition (The University of Chicago Press, 1980), pp. 183-257. 
Table 5. Merchandise Trade and Total Goods Output, Selected Years, 1948-79

Percent unless otherwise indicated

\begin{tabular}{ccccc}
\hline & & \multicolumn{3}{c}{ Merchandise trade as a percent of goods output } \\
\cline { 3 - 5 } Year & $\begin{array}{c}\text { Output of goods } \\
\text { (billions of dollars) }\end{array}$ & Imports $^{\mathrm{a}}$ & Exports & $\begin{array}{c}\text { Total trade } \\
\text { (imports plus } \\
\text { exports) }\end{array}$ \\
\hline 1948 & 154.4 & $4.61^{\mathrm{b}}$ & 8.12 & 12.73 \\
1965 & 338.4 & 5.69 & 8.02 & 13.71 \\
1968 & 421.3 & 7.33 & 8.12 & 15.45 \\
1973 & 604.1 & 10.24 & 11.63 & 21.87 \\
1979 & $1,055.9$ & 14.23 & 16.91 & 31.14 \\
\hline
\end{tabular}

Sources: Goods output-Economic Report of the President, January 1981, p. 240; merchandise trade -Survey of Current Business, various issues.

a. Excludes petroleum.

b. Includes petroleum.

$\$ 8.29$ billion to $\$ 26.77$ billion. ${ }^{28}$ During the same period, net imports of consumer goods grew from $\$ 3.04$ billion to $\$ 17.89$ billion, net imports of fuels and lubricants from $\$ 1.46$ billion to $\$ 38.42$ billion, and net imports of "other" industrial materials from $\$ 4.57$ billion to $\$ 15.06$ billion. ${ }^{29}$ Within these broad categories, competitive changes in steel and automobiles have been especially noticeable. William Branson notes that the United States "has steadily lost its comparative advantage in iron and steel in general," but has maintained competitiveness in advanced steel products. ${ }^{30}$ Trade in automobile products went from a net deficit of $\$ 842$ million in 1968 to $\$ 9.85$ billion ten years later.

On balance, trade is beneficial. The mobility and high educational level of the U.S. labor force are advantages when adaptation is needed. But in an economy that traditionally has had a low level of investment and low capital turnover, the benefits of trade are achieved only with substantial transitional costs. Changing trade patterns can make capital redundant or obsolete. The pace and importance of such change has accelerated for the United States in the 1970s.

Regulation and Defense Spending. The decade of the 1970s has seen the development of major regulatory programs to protect the environ-

28. Ibid., table 3.19, pp. 208-10. The figures are in current dollars. The GNP deflator rose from 82.5 to 150.1 during the same period.

29. "Other" industrial materials do not include agricultural goods, fuels and lubricants, chemicals, or capital goods. Steel imports are an important component of this category.

30. Branson, "Trends in United States International Trade and Instruments," p. 226. 
ment and safety of workers and consumers. These programs have required some new investment and the conversion of some existing capital. Available evidence indicates that only a small fraction of total investment has been allocated directly to pollution control and worker safety. But it is not easy to measure the full costs of converting production methods and modifying product designs.

In 1944 spending on national defense was 41.5 percent of GNP. This percentage fell to 4.1 by 1948 . The shift from guns to butter coming on the heels of the Great Depression created a major problem of capital obsolescence in the 1940s. Defense spending was in the range of 8 to 10 percent of GNP for most of the 1950s and 1960s but fell to 4.6 percent by 1979. This was a much smaller shift than that after World War II, but still caused a noticeable adjustment problem.

\section{CHANGES IN RELATIVE PRICES}

Changes in the mix of production and the movements of resources into and out of sectors are linked to changes in the relative prices of different products. If the decade of the 1970s was a period of exceptional structural change, this should show up in greater relative price dispersion. To test this, for each of three decades, 1949-59, 1959-69, and 1969-79, changes in the deflators for gross product originating for fifty-seven sectors of the private economy ${ }^{31}$ were used to form relative price measures defined by

$$
R P_{i t}=\frac{P_{i t}}{P_{i t-10}} \quad \text { for } i=1, \ldots, 57, \quad t=1959,1969,1979 .
$$

The mean and dispersion of these relative price measures are shown below. Although the price indexes are quite aggregative and could mask important relative price changes within sectors or changes in product quality, they still show that the period of high average inflation in the 1970s was also a time of exceptionally large relative price movements.

$\begin{array}{lccc} & 1949-59 & 1959-69 & 1969-79 \\ \text { Mean } & 1.344 & 1.268 & 1.957 \\ \text { Variance } & 0.091 & 0.069 & 0.319 \\ \text { Coefficient of variation } & 0.224 & 0.207 & 0.289\end{array}$

31. The price deflator series are the same as those used by Hendrik Houthakker, except government was excluded. See Hendrik S. Houthakker, "Growth and Inflation: Analysis by Industry," BPEA, 1:1979, pp. 241-56. 


\section{OTHER APPROACHES TO STRUCTURAL CHANGE}

Structural changes and mix effects have been considered in the productivity literature before, but from a different perspective and with difference conclusions. ${ }^{32}$ One approach has been to decompose overall average labor productivity growth into two parts: the weighted average of the productivity growth rates of the individual sectors of the economy, and the effect on average productivity from workers moving among sectors with differing levels of productivity. For example, it is argued that average productivity rose as workers left agriculture in the 1940s and 1950s (a sector with low labor productivity) and moved into industry (with high labor productivity). When the migration ended in the 1960s, some decline in productivity growth inevitably occurred. Similarly, Lester Thurow argues that growth in average productivity has recently been depressed because much of the employment created in the 1970s took place in low-productivity sectors.

This line of reasoning can be interpreted correctly and incorporated into the central hypothesis of this paper. But the simple intuitive logic behind the approach is not valid. The effect of reallocating labor depends on differences in marginal productivity rather than in average labor productivity. Presumably average productivities differ among sectors because of variations in capital-labor ratios (including differences in human capital and natural resources). Workers moving into a low-productivity sector have low average productivity only because they have little capital with which to work. If total capital services in the economy are correctly measured, it is double counting to suggest that an additional explanation of productivity trends is to be found in mix effects.

There are two possibilities for salvaging the intuition about the agriculture and service sectors. One is to argue that market inefficiencies have resulted in differences in marginal products. This may be true, especially for the earlier move away from agriculture, although it is doubtful that such inefficiencies contribute to understanding the recent experience or the effect of industry mix shifts in general.

32. See William D. Nordhaus, "The Recent Productivity Slowdown," $B P E A$, 3:1972, pp. 493-536; and Lester C. Thurow, "The Productivity Problem," paper prepared for the Ontario Economic Council, November 1980. 
The second possibility is to consider the consequence at the sectoral level of the kind of capital obsolescence that has been hypothesized in this paper. If the industrial sector of the economy has been hit by structural change and its effective available capital input reduced, it is likely that employment creation in this sector would be slowed and that the relative share of employment in the service sector would rise. Thus Thurow's observation about where the jobs have come from in the 1970s may be a symptom of the decline of capital services suggested here. In general, shifts in the mix of employment that correspond to changes in economy-wide capital services will show up as slowdowns in average productivity growth. The slowdown, however, is accounted for by the lower ratio of capital services to labor in the aggregate.

\section{Capital Services and Market Value}

Under certain assumptions, capital obsolescence can result in a decline in effective capital services and hence in labor productivity growth. This will be shown in a vintage capital model in which the market value of the capital stock provides an accurate measure of the flow of effective capital services. It is based upon the vintage capital model developed by Robert Solow. ${ }^{33}$ There is only one sector, and output $Q$ is either for consumption or for investment. Thus the price of new capital goods is always equal to unity. Once a unit of the output has been formed into capital, however, the state of technology at the time it was produced is embodied in the capital good. This means that at time $t$ the output, $Q_{v}(t)$, from capital of vintage $v$ is

$$
Q_{v}(t)=A_{v}(t) F\left[L_{v}(t), K_{v}(t), v\right],
$$

where $F$ is the vintage production function, $L_{v}$ is the amount of labor employed on capital of vintage $v\left(K_{v}\right)$, and $A_{v}$ is a multiplicative term to be explained below. It is assumed that technological progress is taking

33. Robert M. Solow, "Investment and Technical Progress," in Kenneth J. Arrow, Samuel Karlin, and Patrick Suppes, eds., Mathematical Methods in the Social Sciences, 1959 (Stanford University Press, 1960), pp. 89-104. John Shoven and Arthur Slepian have considered the effect of energy and obsolescence on market valuation. See John B. Shoven and Arthur P. Slepian, "The Effect of Factor Price Changes on Replacement Investment and Market Valuation," Discussion Paper 19 (Workshop on the Microeconomics of Inflation, Stanford University, October 1978). 
place so that for increasing $v$ each new vintage of capital is more productive.

After an initial investment, $I_{v}$, in vintage $v$ capital (that is, for $t \geq v$ ), two kinds of deterioration take place. The first is that the capital suffers physical decline; it wears out. This is assumed to take the form of exponential decay at a rate $\delta$. Thus the amount of vintage $v$ capital available at time $t$ is

$$
K_{v}(t)=\cdot I_{v} e^{-\delta(t-v)} \quad t \geq v .
$$

The second deterioration comes about because the output itself produced by $K_{v}(t)$ becomes obsolete. This is used to capture both the effect of structural change in a world in which capital is product-specific and the effect of a factor-price change on the value-added produced by old capital. ${ }^{34}$ These events cannot be captured realistically in a model as simple as this one. But technological change is also a complex process, and people accept very simple modeling of that process. To allow for obsolescence induced by structural change, it is assumed that

$$
A_{v}(t)=A e^{-\theta(t-v)},
$$

which implies that the effective output produced by old capital declines as capital ages.

Workers are assumed to earn the same real wage, $W(t)$, wherever they work. Because of this common wage and because new vintages of capital are more productive than old ones, labor is gradually withdrawn from old capital. In practice this reduction in the utilization of old capital usually takes the form of a reduction in the number of shifts worked or the number of short- or long-term plant closings, because variations in the flow of capital services deriving from a given capital stock are the principal form of ex-post capital-labor substitution (although not the only form). The specification of the production function in equation 5 assumes a "putty-putty" technology, which implies that old capital does not die at some specific point in time, but instead gradually fades away. This explanation does capture, in a general way, the empirically important phenomenon of declining utilization.

In general, vintage models have no capital aggregates. The entire his-

34. If the price of energy rises and new capital is more energy-efficient, its valueadded is greater than that of old capital. One could also model the retrofitting of old capital as a process of diverting part of its output in order to make the change. 
tory of investment must be specified to determine output. In the special case of a Cobb-Douglas production function, there is an aggregate and the model can be analyzed simply. It is assumed, therefore, that the vintage production function can be written as

$$
F(\cdot)=e^{\gamma v} L_{v}(t)^{\alpha} K_{v}(t)^{1-\alpha} .
$$

The condition that the employment of labor on capital of vintage $v$ be determined by equality between the marginal product and the wage gives

$$
L_{v}(t)=I_{v}\left(\frac{\alpha A}{W}\right)^{1 /(1-\alpha)} e^{a v} e^{-b t},
$$

where $a$ is $\delta+(\theta+\gamma) /(1-\alpha)$ and $b$ is $\delta+\theta /(1-\alpha)$. This condition determines the employment on any vintage $v$ depending on the level of the economy-wide wage, $W$. For the economy as a whole, however, the wage is endogenous and determined by total employment, $L(t)$. Total employment is the sum of employment on all vintages and is expressed as

$$
L(t)=\int_{-\infty}^{t} L_{v}(t) d v
$$

Substituting for $L_{v}$ from equation 9 yields

$$
L(t)=\left(\frac{\alpha A}{W}\right)^{1 /(1-\alpha)} e^{-b t} \int_{-\infty}^{t} e^{a v} I_{v} d v,
$$

which determines the wage in the economy for any level of total employment and path of investment.

Output from capital of vintage $v, Q_{v}$, can be determined as a function of the wage, $W$, the amount of vintage $v$ capital in existence (equal to $\left.I_{v} e^{-\delta(t-v)}\right)$ and parameters of the model. Thus

$$
Q_{v}(t)=A I_{v}\left(\frac{\alpha A}{W}\right)^{\alpha /(1-\alpha)} e^{a v} e^{-b t} .
$$

Total output for the economy as a whole then is the sum of the output from all the vintages,

$$
\begin{aligned}
Q(t) & =\int_{-\infty}^{t} Q_{v}(t) d v \\
& =A\left(\frac{\alpha A}{W}\right)^{\alpha /(1-\alpha)} e^{-b t} \int_{-\infty}^{t} e^{a v} I_{v} d v .
\end{aligned}
$$

A comparison of equation 11 determining total employment and equa- 
tion 13 determining total output reveals that the endogenous wage, $W$, can be substituted out and total output can be expressed as a function of total employment and the integral over $I_{v}$. If a variable $\Gamma$ is defined by

$$
\Gamma(t)=\int_{-\infty}^{t} e^{a v} I_{v} d v
$$

total output can be expressed very simply as

$$
Q(t)=A e^{-b(1-\alpha) t} L(t)^{\alpha} \Gamma(t)^{1-\alpha} .
$$

This is one form of an aggregate production function, and the task now is to relate $\Gamma(t)$ to the market value of the capital stock. To determine market value, the quasi-rent at time $t$ of vintage $v$ capital is determined. This is defined as $\rho_{v}(t)$ and is just equal to the marginal product of vintage $v$ capital. Taking the derivative $\partial Q_{v} / \partial K_{v}$ yields an equation involving $L_{v}$, the employment on vintage $v$ capital, $I_{v}$, and the exponential terms in $t$ and $v$. Then using the previous condition in equation 9 that determined $L_{v}$ as a function of $W$ and substituting out the wage using equation 11 gives the quasi-rent, $\rho_{v}(\mathrm{t})$, as a function of total employment in the economy and the capital integral $\Gamma$,

$$
\rho_{v}(t)=(1-\alpha) A\left(\frac{L(t)}{\Gamma(t)}\right)^{\alpha} e^{(a-\delta) v} e^{-(\theta-\delta \alpha) t} .
$$

The market value of a unit of vintage $v$ capital is then $p_{v}(t)$ given by

$$
p_{v}(t)=\int_{t}^{\infty} \rho_{v}(\tau) e^{-(\delta+r)(\tau-t)} d \tau
$$

which is the present value of the stream of quasi-rents, with a discount rate, $r$. At time $t$ there are $I_{v} e^{-\delta(t-v)}$ units of vintage $v$ capital in existence, so the market value of all units of vintage $v$ capital is

$$
V_{v}(t)=p_{v}(t) I_{v} e^{-\delta(t-v)} .
$$

If investment is positive, the present value of the stream of quasi-rents of a unit of new capital of vintage $t$ is equal to its purchase price. Because this price is equal to unity in a one-sector model, this condition becomes

$$
p_{t}(t)=1=\int_{t}^{\infty} \rho_{t}(\tau) e^{-(\delta+r)(\tau-t)} d \tau .
$$

In the terminology of the Tobin-Brainard investment model, this is the condition that marginal $q$ equals unity ${ }^{35}$ it can simplify greatly the calcu-

35. James Tobin and William C. Brainard, "Asset Markets and the Cost of Capital," in Bela Belassa and Richard Nelson, eds., Economic Progress, Private Values, and Public Policy: Essays in Honor of William Fellner (Amsterdam: NorthHolland, 1977), pp. 235-62. 
lation of the market value of old capital. Equation 16 with $v=t$ can be substituted into equation 19. In calculating $p_{v}(t)$ almost everything drops out, resulting in

$$
V_{v}(t)=I_{v} e^{-a(t-v)} .
$$

Then the market value of the entire capital stock is the sum of the market values of all the vintages,

$$
V(t)=\int_{-\infty}^{t} V_{v}(t) d v=e^{-a t} \Gamma(t) .
$$

This is the relation between the capital integral $\Gamma$ and the market value of capital; substituting into equation 15 yields

$$
Q(t)=A e^{\gamma t} L(t)^{\alpha} V(t)^{1-\alpha} .
$$

Thus this model of vintage capital does have a remarkable property. In the simple case of a Cobb-Douglas technology, there is an aggregate production function, and the aggregate measure of capital services in that function is equal to the perfect foresight market value of the capital stock. The reason is that the market value depends upon the stream of quasirents generated by the capital; each vintage of capital is weighted by its quasi-rent, and that is just the right set of weights to produce the aggregate measure of capital services. The model comes out so neatly because, in the framework of Cobb-Douglas and putty-putty technology, old capital is equivalent to some smaller quantity of new capital. So a simple weighting system works exactly right. In a more general model, that would not be true.

\section{PRODUCTIVITY GROWTH AND CHANGES}

\section{IN THE PARAMETERS}

The aggregate production function just obtained could be used directly to track output or productivity trends or to compute the rate of total factor productivity growth, if the observed actual market value were to be used for the perfect foresight market value. Below I combine actual market value and conventional capital stock measures to construct a capital input index. But before turning to that index, some additional implications of the theory are worth considering.

For simplicity assume that total labor input, $L(t)$, grows at a constant 
rate, $g_{L}$. Then from equation 22 the rate of output growth is given by

$$
\frac{d \ln Q}{d t}=\gamma+\alpha g_{L}+(1-\alpha) \frac{d \ln V}{d t} .
$$

The growth rate of $V$, in turn, depends upon the rate of investment, $I$, and on the parameters of the model. Specifically,

$$
\begin{aligned}
\frac{d V}{d t} & =\frac{d}{d t}\left[e^{-a t} \Gamma(t)\right]=-a V+I \\
\frac{d \ln V}{d t} & =-\delta-\left(\frac{\theta+\gamma}{1-\alpha}\right)+\frac{I}{V}
\end{aligned}
$$

New I obviously augments the stock of physical capital and its market value. Physical depreciation diminishes the stock of physical capital so that the higher is the depreciation rate, $\delta$, the lower is the growth rate of market value for any given level of gross investment, $I$. It is assumed henceforth that $\delta$ is fixed. Technical change embodied in new capital (occurring at rate $\gamma$ ) and obsolescence of the output from old capital (occurring at rate $\theta$ ) are exactly equivalent in their impact on market value, although they are not equivalent in the model. The larger the sum of $\gamma$ and $\theta$ is, the lower the growth rate of market value. The reason is that an increase in either parameter makes new capital relatively more attractive than old and lowers the relative price of old capital and hence market value.

The discussion of the model thus far is based upon values of the parameters that are constant over time. A complete analysis of the case in which these parameters change is quite feasible in principle but awkward in practice. To show the most important implications of parametric shifts it is easier to ask how the relations in the model are affected by alternative parameter values. I consider first a change in $\gamma$.

\section{A DECREASE IN THE RATE OF EMBODIED TECHNICAL CHANGE}

If there is an increase or a decrease in the rate of embodied technical change, $\gamma$, there is no direct impact on the rate of output or labor productivity growth. If the expression for the growth rate of $V$ in equation 24 is substituted into equation 23 , the result is

$$
\frac{d \ln Q}{d t}=\alpha g_{L}+\left(\frac{I}{V}-\delta-\frac{\theta}{1-\alpha}\right)(1-\alpha) .
$$


The $\gamma$ has simply dropped out of the expression. Thus changes in $\gamma$ alter the rate of output and labor productivity growth only through their effects on investment, $I$, and market value, $V$. The intuitive reason for this is that if, for example, $\gamma$ declines, there are two offsetting effects: a smaller productivity increment is associated with new capital as a result of its technical advantage, but old capital retains more labor and produces more output, so that market value $V$ is increased by the decline in $\gamma{ }^{36}$

This increased rate of growth of capital services and market value, $V$, will lead to a decline in $I / V$ for any given path of gross investment. This in turn decreases output growth, and the process continues until the decline in output growth and productivity growth is just equal to the reduction in the rate of technical change, $\gamma$. This is the result one would expect.

Finally, the path of investment itself will in general be altered by the change in $\gamma$. The rate of economic depreciation is reduced by such a decline and this increases the net rate of profit. If the supply of savings to the business sector is elastic, it will increase the rate of gross investment, acting as a partial offset to the decline in output and labor productivity growth. ${ }^{37}$

\section{AN INCREASE IN THE RATE OF OBSOLESCENCE}

Although variations in the rate of output obsolescence, $\theta$, and in the rate of embodied technical change, $\gamma$, are equivalent in their impact on capital services and market value, they have different effects on productivity. A rise in $\gamma$ increases the steady-state rate of output and productivity growth even though it reduces the effective flow of capital services from

36. Even a discontinuous change in a parameter such as $\gamma$ will not cause a discontinuous change in $V$, however. Market value in $t$ depends upon the relative productivity of old vintage capital and capital purchased in $t$. If $\gamma$ has remained constant up to time $t$ and then changes for all time after $t$, this has only an infinitesimal effect on the productivity of capital purchased from $t$ to $t+d t$. Since the price of new capital is always unity, the relative price of old vintage $v$ capital, therefore, changes continuously. In general, when a parameter shifts it alters both the expected future path of investment and the discount rate. Under the strong equilibrium conditions of the model (particularly equations 17 and 19), the resulting paths of these variables will be such that market value does not jump.

37. That a decline in the rate of technical progress encourages investment may seem counterintuitive. In a model with disembodied technical change this would not be true, but embodied technical change is associated with capital obsolescence and this turns out to be the dominant factor. This point is made by Robert M. Solow in Capital Theory and the Rate of Return (Amsterdam: North-Holland, 1963), p. 63. 
old capital. An increase in $\theta$, however, simply reduces the effective flow of capital services from old capital.

If the economy has been growing in a period of relative tranquillity and then passes into a period of structural change, this is modeled as an increase in $\theta$. There will be an immediate impact on productivity growth. Labor is withdrawn from old capital and increased on new capital. The effective flow of capital services declines and the rate of growth of wages declines. New capital goods are just as advanced technologically as they were before. But the slower growth of wages is the market signal to owners of new capital goods to use a more labor-intensive technique in production. Thus both the increment to labor productivity growth coming from new additions to the capital stock and overall labor productivity growth are reduced.

The direct impact of an increase of 1 percentage point in the obsolescence parameter is a decrease of 1 percentage point in labor productivity growth. Over time, however, the decrease in $V$ associated with the decrease in capital services means that $I / V$ rises for a given growth path of gross investment. This process must continue until the reduction in the productivity growth rate has been eliminated. The direct impact of an increase in $\theta$ on productivity growth is, therefore, temporary.

The indirect impact of an increase in $\theta$ on productivity is that it increases economic depreciation, reduces the net rate of profit, and discourages investment. Thus unless some offsetting policy change or other stimulus to investment is provided, a permanent increase in $\theta$ discourages capital formation and productivity growth in the long run.

If the economy ever returns to a period without structural change, so that $\theta$ returns to its original level, a productivity growth bonus will result.

THE IMPACT OF PARAMETER CHANGES

ON MARKET VALUE AND TOBIN'S $q$

The puzzling trends in the ratio of the market value of corporate capital to the replacement value of the capital stock (Tobin's average $q$ ) have received almost as much attention as the productivity growth slowdown. It is easy to see in the vintage capital model what happens to this ratio under some assumptions about how a standard capital stock measure is computed.

Suppose that at some initial time $(t=0)$ the estimated size of the 
physical capital stock is $K(0)$ and is actually equal to the market value $V(0)$. Average $q$ is initially equal to unity. Suppose further that the growth of $K$ over time is then computed using gross investment, $I$, and an assumed proportional depreciation rate, $d_{K}$, that at time zero accurately reflects the true depreciation rate-both economic and physical depreciation. Thus,

$$
d_{K}=\delta+\frac{\theta(0)+\gamma(0)}{1-\alpha} .
$$

As long as there is no change in $\gamma$ or $\theta$, the estimated capital stock will remain equal to market value and will provide an accurate measure of the flow of capital services.

But suppose $\gamma$ or $\theta$ changes. If $\gamma$ declines, market value, $V$, will rise for the reasons given earlier. This means $V$ will rise relative to the unaltered estimates of the capital stock. If the decline in $\gamma$ is 1 percentage point, capital's share of income $(1-\alpha)$ is 0.25 , and the ratio of gross investment to the capital stock is 0.12 , then $V$ will rise until measured average $q$ reaches 1.5 . If the replacement cost value of the capital stock is calculated correctly, with economic depreciation slower than before because of the decline in $\gamma$, its value will just keep up with the market value and the value of $q$ will remain at 1.0. This correctly estimated $K$ will continue to measure properly the flow of capital services.

Similarly, if $\theta$ increases by 1 percentage point, $V$ declines relative to the (mis-) measured value of the capital stock, and this process continues until $q$ has reached 0.75 . A change of 2 percentage points in $\theta$ results in a final $q$ value of 0.60 .

Fairly moderate changes in technical change or obsolescence thus imply very substantial changes in $q$, the ratio of the market value of capital to the estimated replacement cost of the net stock. As I describe below, changes in market value have been so great that they overexplain the productivity slowdown if market values are used to measure the flow of capital services. Turning this around implies that, at most, capital obsolescence can explain only a part of the observed decline in market value. This point needs to be stressed. Nevertheless, the link that this model implies between productivity trends and the puzzling large trend movements in $q$ provides important empirical support for the basic hypothesis of the paper. It also should be emphasized that anyone who argues that the recent decrease in productivity growth has been due to a decline in 
the rate of embodied technical change has to explain why the trend in average $q$ has been exactly in the wrong direction. Slower technical change maintains the value of existing capital and should thus raise measured $q$.

\section{GROSS AND NET PROFITS}

The vintage capital model predicts that if capital stock becomes obsolete, average $q$, as it is usually measured, will decrease. One reason that the observed decline in average $q$ has seemed so puzzling is that conventional profit calculations have shown the profit rate holding up fairly well in the 1970s. Thus what this vintage model predicts about the behavior of gross and net profits is worth considering.

Gross profits-the total stream of quasi-rents from capital of all vintages-are predicted to remain a constant share of output because the aggregate production function is Cobb-Douglas. This means that if the flow of capital services is reduced because of obsolescence, there is no reason to expect an equivalent decline in gross profits. Rather, the growth rate of gross profit will slow along with the growth of output. Obsolescence does reduce the quasi-rents from old capital; and the decline in market value reflects the reduction in these quasi-rents. But the initial quasi-rents from new capital rise and maintain the level of total gross profit. This high initial quasi-rent is expected to decline rapidly as the new capital becomes old and obsolete.

A study by William Brainard, John Shoven, and Laurence Weiss considers the relation between profit stream and market value. They compute a cash-out case in which "any new investment is assumed to break even; the present value of the firm is solely a reflection of past investment decisions." ${ }_{38}$ They find the decline in the market valuation of corporate capital to be a major puzzle using this cash-out calculation. But they ignore obsolescence and assume the quasi-rents from old and new capital are the same up to the point at which old capital is scrapped. They explain why this will give different results from those of a vintage model such as the one used in this paper: "The assumption that capital is a one hoss shay with returns to a unit of capital independent of its age is artificial. Moreover, it does not explicitly take into account obsolescence, probably the

38. William C. Brainard, John B. Shoven, and Laurence Weiss, "The Financial Valuation of the Return to Capital," BPEA, 2:1980, p. 458. 
most important factor in determining actual lifetimes. Ignoring obsolescence leads to an underestimate of the returns on new capital and an overestimate of the returns on old." ${ }^{39}$ Their calculation assigns the total gross profit evenly among capital of all ages. The vintage model does not.

A conventional calculation of net profit or net rate of return to capital uses a depreciation rate that does not vary much over time. The assumption of equation 26, for example, implies that total depreciation is $d_{K} K$. The estimate of net profit is then gross profit (denoted as $\pi$ ) minus $d_{K} K$; the estimate of the net rate of profit is $\left(\pi-d_{K} K\right) / K$. Suppose the conventional capital stock estimate, $K$, grows at about the same rate as output. The vintage capital model predicts that $\pi$ also grows at the same rate as output. It follows that a conventional estimate of the net profit rate is predicted to remain constant, even when capital becomes obsolete.

The correct measure of net profit, however, declines sharply with the obsolescence of capital. Correct economic depreciation is equal to $\delta+(\theta+\gamma) /(1-\alpha)$. The first term is the physical depreciation; the second reflects economic depreciation. If the rate of obsolescence, $\theta$, increases by 1 percentage point, the rate of economic depreciation increases by 4 points because $1-\alpha=0.25$. It is this increase in economic depreciation and decrease in net profit that is reflected in the decline in market value.

These predictions about profit accord reasonably well with developments in the nonfinancial corporate sector. The nonlabor share of gross income has declined somewhat in the postwar period from 30.0 percent in 1948 to 25.1 percent in 1973, and 25.7 percent in 1979. Output grew at an average of 4.6 percent a year from 1948 to 1973 and only 2.9 percent annually from 1973 to 1979 . The growth rate of gross profit declined in the 1970s while the conventional measure of capital stock has grown roughly at the same rate as output. The constancy of the conventionally measured rate of return on capital has been noted by Martin Feldstein and Lawrence Summers and by Brainard, Shoven, and Weiss. ${ }^{40}$

The retention rate of corporations has increased and there has been a corresponding slowdown in dividend growth since 1968. Real dividends paid out by nonfinancial corporations grew by 3.95 percent a year from

39. Ibid., p. 458.

40. Martin Feldstein and Lawrence Summers, "Is the Rate of Profit Falling?" $B P E A, 1: 1977$, pp. 211-27; and Brainard, Shoven, and Weiss, "The Financial Valuation of the Return to Capital." 
1948 to 1968 but were at about the same level in 1979 as in 1968 . Corporations were paying out a much smaller fraction of gross profit to their stockholders in the 1970s than in the 1960s. This behavior is consistent with a realization by managers and stockholders that true net profit has declined relative to gross profit-that is, economic depreciation has increased.

\section{Actual Market Value}

The theoretical model of the preceding section shows that changes in the ratio of the market value of capital to the measured physical capital stock could provide an estimate of changes in the flow of capital services relative to the measured capital stock. But the model uses some very restrictive assumptions, and the market value in question is a perfect foresight market value. In practice there are determinants of market value and of its ratio to capital, average $q$, that were not considered. Some of these reinforce the use of market value as a measure of capital services, but some of them weaken the relation.

\section{IN TANGIBLE CAPITAL}

Intangible capital - patents, good will, organizational capital, and the appropriable part of firm-specific human capital-is counted in a firm's market value but not as part of its physical capital stock. This fact gives the use of market value as a measure of capital an important advantage for productivity analysis. It may well be that the value of the stock of research and development "capital" has diminished in the past ten years as a result of the rise in the price of energy or of other structural changes, or because of a reduction in government-sponsored research.

On the other hand, if firms have monopoly power that changes over time, the change will be reflected in market value. But there will not be a corresponding movement of capital services. Eric Lindenberg and Stephen Ross find no relation between movements in the four-firm concentration ratio and movements in $q{ }^{41}$ But it may be that foreign competition in some sectors has eroded market power.

41. Eric B. Lindenberg and Stephen A. Ross, "Tobin's $q$ Ratio and Industrial Organization," The Journal of Business, vol. 54 (January 1981), pp. 1-32. 


\section{TAXES AND INTEREST RATES}

The market value of capital is the present discounted value of the stream of quasi-rents. It can be altered, therefore, by taxes levied on the profit stream or by changes in the rate at which the stream is discounted. It has been argued that the effective tax rate on corporate income and the effective discount rate have both risen in the 1970s, perhaps as a result of inflation or increased risk.

The important point is that variations in taxation and interest rates affect the present value of the returns to both old and new capital. If it is true that tax or discount rates have risen, both market value and the size of the capital stock should have been depressed. In equilibrium, average $q$ should not be altered by a change in the discount rate or by general taxation of corporate income. Only those taxes that affect old and new capital differently will change their relative price-that is, will change average $q$ in the long run. ${ }^{42}$

\section{DISEQUILIBRIUM}

Consideration of taxes and interest rates does raise the possibility of disequilibrium movements in average $q$. The prices of old and new capital are equalized by variations in the flow of investment. But if there are costs of adjusting the capital stock or if sellers of capital goods ration by stretching delivery times rather than raising price, the market value of old capital can change relative to the price of new capital in the short run, with no change in capital services.

But disequilibrium movements in average $q$ should be short run. It is hard to accept disequilibrium as an explanation for the observed persistent trends in average $q$. The striking feature of the ratio of gross investment to the capital stock in the nonfinancial corporate business sector is how stable it has been. Average $q$ was low in the 1940s and the 1970s

42. The investment tax credit is an example of such a tax, and under some assumptions the tax on dividends may be another. The paper by Lawrence Summers in this issue investigates the impact of taxes. I am not persuaded that his assumptions are the most appropriate. But certainly in principle a tax-adjusted $q$ series should allow the construction of a capital services measure that is better than the actual market value. 
and yet the rate of investment was as high during those periods as its average for the 1950s and 1960s. All estimates of measured $q$ were below equilibrium from 1973 to 1979, which should have implied that corporations were trying to shed capital. In fact, however, they invested at a fairly high rate-enough to raise their estimated net capital stock by 17 percent. $^{43}$

\section{IRRATIONALITY AND VOLATILITY}

If investors are ignorant or irrational or do not predict future returns well, market value could be a poor guide to capital services. Franco Modigliani and Richard Cohn have suggested that stockholders discount future earnings by the nominal interest rate rather than by the real rate. ${ }^{44}$ The increase in inflation and the nominal rate of interest, they argue, can explain the decline in market value in the 1970s. There are several problems with this hypothesis. First, as was pointed out earlier, real interest rate illusion should depress both market value and investment but not average $q$ (except in the short run). Second, the Modigliani and Cohn model incorporates an implausible asymmetry. They assume that discounting earnings with the nominal interest rate is always incorrect, but that is not true. My reading of Wall Street pundits is that they do their analyses throughout in nominal dollars. If sales and earnings projections are made in expected nominal dollars, the correct present value is obtained by using the nominal interest rate. In fact, given the way tax laws are written, it may make excellent sense to do it that way. It is only if Wall Street makes real earnings projections and discounts these by the nominal interest rate that the wrong answer is derived. A third problem with the Modigliani-Cohn model is that it does not explain why $q$ was

43. The association between disequilibrium movements of average $q$ and investment that is described in the Tobin-Brainard investment model should allow one to construct an adjusted market value that removes some disequilibrium movements by using observed investment behavior. I have begun to experiment along those lines. The fact that investment has remained fairly high in the late 1970s despite the depressed level of $q$ is a supporting fact for the hypothesis of this paper. By contrast, the rapid increase in market value in the mid-1960s was associated with an investment boom from 1965 to 1969 , which suggests there was some disequilibrium.

44. Franco Modigliani and Richard A. Cohn, "Inflation, Rational Valuation and the Market," Financial Analysts Journal, vol. 35 (March-April 1979), pp. 24-44. 
lower in the late 1940 s, when nominal interest rates were less than three percent, than it is today. ${ }^{45}$

It has also been argued that the stock market reveals irrationality because it is so volatile. This is a view with which I partly agree. The usual reason given is that the price of a representative share is much more variable than the present value of the ex post earnings. But recorded earnings tell only part of the story. If the hypothesis of this paper is correct, changes in parameters of technical change or obsolescence can result in very large capital gains or losses to holding old capital, as is shown in the theoretical model above. Thus the returns to holding shares are much more uncertain than they look. Nonetheless, it is true that speculative swings do affect market values at times. There was a speculative boom in stocks in the mid-1960s without a corresponding increase in capital services, and the market was probably overly depressed in the mid- and late 1970s.

It is important to keep the correct perspective on market rationality. There are plenty of foolish people buying and selling stocks or even buying and selling information about stocks. And certainly, ex post, one will be able to find many stocks that were undervalued or overvalued. Indeed, one can look back and find periods when stocks as a whole were under- or overvalued. It is also true that some corporate accounting practices are puzzling or irrational. But if the efficient markets hypothesis has any application in economics it is surely to stock and bond markets. The standard estimates of the value of corporate capital are part of the set of information readily available to the market, as are data on all major industries and most of the large firms within these industries. The basic presumption of economic analysis should surely be that clear and persistent trends in variables have a rationale.

The possibilities for arbitrage by corporate insiders provide an important force drawing together the prices of old and new capital. First, corporate officers are generally major stockholders. If they know that the value of their own company's stock has gotten far out of line with their own estimate of the worth of the capital, they can profit from this information. But more important, they can take advantage of the active market in old capital. Rather than buying new capital goods, managers can

45. The aftermath of the Great Depression and World War II, however, makes it plausible that the capital stock was obsolete in the 1940s-an explanation in line with the model given here. 
buy other companies, buy or sell subsidiaries, or buy or sell particular plants. These transactions happen with some frequency.

PUTTY-CLAY CAPITAL

The theoretical model above assumes technological embodiment but allows ex post capital-labor substitutability. It was shown that an exact relation exists in that model between the market value of the capital stock and the effective flow of capital services. Without the simple and tractable features of the putty-putty model, the link between $V$ and effective capital services is altered, but not broken.

A putty-clay model represents the other extreme in substitutability by assuming that once capital is in place it can only be put to use with a fixed relation between capital-hours and labor-hours. It should be assumed that, even in a putty-clay model, the utilization rate can vary.

For example, if a plant with these characteristics is in place and operating and there is an increase in the price of energy, in the short run there is no change made in production method and hence no change in capital services. The price of the product is simply raised to cover the increased fuel costs. Over time two things may happen. The capital may be retrofitted to improve energy efficiency; alternatively, the capital may remain unaltered but as new, more fuel-efficient capital becomes available, competition begins to drive down the price of the product relative to the operating costs of the old plant. This implies that the stream of quasi-rents from the old plant declines more rapidly as a result of the energy price change.

Such a drop in quasi-rents remains closely linked to a decrease in capital services even in a putty-clay context; it must be associated with a decline in the average utilization rate, with more rapid scrapping of the plant, or both. Introducing extra shifts involves a wage penalty and a productivity penalty. After the energy price rise, the point at which adding shifts becomes unprofitable is reached more quickly in the lifetime of the capital. The capital is scrapped sooner because the quasi-rent reaches zero sooner.

The implications of this process are as follows. The perfect foresight market value of the plant falls quickly following the energy price rise as the future drop in quasi-rents is anticipated; but now the reduction in capital services follows behind the decline in market value. Thus the putty-clay 
differs from the putty-putty model in a predictable way: an adjustment lag is introduced between market value and capital services. ${ }^{46}$

\section{Empirical Application of Market Value}

The conclusion of the preceding sections is that real market value should contain valuable information about the flow of capital services. To implement this idea in analyzing productivity, I have adopted the series constructed by Daniel Holland and Stewart Myers for average $q$ in manufacturing and nonfinancial corporations during the 1948-78 period. ${ }^{47}$ Their $q$ estimates are used to form indexes of capital input. As the preceding discussion shows, there are many reasons to be cautious about using real market value exclusively to measure capital services. Therefore, each index of capital input is a weighted geometric average of real market value and the conventional series for the stock of equipment and structures. In this combined capital index two-thirds of the weight comes from capital stock and one-third from real market value. ${ }^{48}$

A computation of total factor productivity growth was then made using the following relation:

$$
\Delta \ln Q=\alpha \Delta \ln L+(1-\alpha) \Delta \ln C K+\epsilon,
$$

where

$$
Q=\text { output }
$$

$L=$ labor input

$C K=$ the combined capital index measuring capital input

$\alpha=$ labor's share of income

$\epsilon=$ the estimate of the rate of growth of total factor productivity.

46. Actual market value may or may not lead to changes in capital services. Investors may rely on current quasi-rents if they are not able to foresee the future pattern of returns exactly.

47. Daniel M. Holland and Stewart C. Myers, "Profitability and Capital Costs for Manufacturing Corporations and All Nonfinancial Corporations," American Economic Review, vol. 70 (May 1980, Papers and Proceedings, 1979), pp. 320-25.

48. I have also formed a capital index using the $q$ series for nonfinancial corporations by George von Furstenberg and by Jeremy Bulow and John Shoven. And I have used a broader definition of capital (all tangible assets) to combine with market value in forming the capital index. The results were similar to those discussed in the present text. See George M. von Furstenberg, "Corporate Investment: Does Market Valuation Matter in the Aggregate," BPEA, 2:1977, pp. 347-97; and Jeremy I. Bulow and John B. Shoven, "Inflation, Corporate Profits, and the Rate of Return to Capital," Conference Paper 107 (National Bureau of Economic Research, March $1981)$. 
Table 6. Effect of Capital Measure on Growth Rates of Capital and of Total Factor Productivity, Selected Sectors and Periods, 1948-78

Percent

\begin{tabular}{|c|c|c|c|c|}
\hline \multirow[b]{2}{*}{ Sector and year } & \multicolumn{2}{|c|}{ Capital measure } & \multicolumn{2}{|c|}{ Total factor productivity } \\
\hline & $\begin{array}{l}\text { Equipment } \\
\text { and structures }\end{array}$ & $\begin{array}{c}\text { Combined } \\
\text { capital index }\end{array}$ & $\begin{array}{l}\text { Using equipment } \\
\text { and structures }\end{array}$ & $\begin{array}{c}\text { Using } \\
\text { capital index }\end{array}$ \\
\hline \multicolumn{5}{|c|}{ Nonfinancial corporations } \\
\hline $1948-68$ & 3.88 & 4.64 & 2.14 & 1.93 \\
\hline $1968-73$ & 4.16 & 3.11 & 1.76 & 2.04 \\
\hline $1973-78$ & 3.14 & 0.01 & 0.81 & 1.66 \\
\hline \multicolumn{5}{|l|}{ Nonfarm business } \\
\hline $1948-68$ & 4.25 & 5.00 & 1.70 & 1.45 \\
\hline $1968-73$ & 4.40 & 3.20 & 1.09 & 1.49 \\
\hline $1973-78$ & 2.94 & 0.32 & 0.72 & 1.77 \\
\hline \multicolumn{5}{|l|}{ Mánufacturing } \\
\hline $1948-73$ & 3.06 & 3.57 & 2.27 & 2.10 \\
\hline $1973-78$ & 3.70 & 0.95 & 0.65 & 1.98 \\
\hline
\end{tabular}

Sources: The data for equipment and structures are from the Bureau of Economic Analysis; the combined capital index and the total factor productivity are calculated by the author based on data from the Bureau of Labor Statistics, from the Board of Governors of the Federal Reserve System, and from Daniel M. Holland and Stewart C. Myers, "Profitability and Capital Costs for Manufacturing Corporations and All Nonfinancial Corporations," American Economic Review, vol. 70 (May 1980, Papers and Proceedings, 1979), pp. 320-25.

The findings for nonfinancial corporations, nonfarm business, and manufacturing are shown in table 6. The results for nonfinancial corporations give support to the hypothesis that trends in market value are indicative of trends in capital services. The slowdown in total factor productivity is greatly reduced using the combined capital index.

The market value of capital in the nonfarm business sector was estimated by applying the $q$ series for nonfinancial corporations to the capital stock series for nonfarm business. Then a combined capital index was formed as before. The table indicates that the combined capital index "overexplains" the slowdown because it suggests that the growth of total factor productivity accelerated in 1973-78.

The productivity slowdown began in manufacturing after 1973, so the table shows periods before and after that year for this sector. The results indicate little slowdown in the growth of total factor productivity in the calculation using the capital index.

I also made estimates for the production function using the combined capital index for the three sectors. For nonfinancial corporations, the re- 
sults were

$$
\begin{gathered}
\Delta \ln Q=\begin{array}{c}
0.0200+0.767 \Delta \\
(9.7) \quad(13.0) \quad
\end{array} \quad(4.0) \quad 0.233 \Delta \ln C K-0.0107 \Delta L U \\
\bar{R}^{2}=0.924 \quad \rho=-0.52 ;
\end{gathered}
$$

for nonfarm business,

$\Delta \ln Q=0.0191+0.812 \Delta \ln L+0.188 \Delta \ln C K-0.0085 \Delta L U$

$$
\begin{aligned}
(11.7) \quad(20.2) \quad(4.7) \\
\bar{R}^{2}=0.928 \quad \rho=-0.44 ;
\end{aligned}
$$

and for manufacturing,

$$
\begin{aligned}
& \Delta \ln Q=0.0240+0.843 \Delta \ln L+0.157 \Delta \ln C K-0.0314 \Delta L A Y O F F \\
& \text { (5.7) (27.2) (5.1) (-6.6) } \\
& \bar{R}^{2}=0.958 \rho=0.47 \text {. }
\end{aligned}
$$

A cyclical adjustment variable (with mean adjusted to zero) was included in all equations - the change in the Perry-leading unemployment rate for the nonfinancial corporations and nonfarm business and the change in the layoff rate for manufacturing. The equations shown were constrained to give constant returns to scale. ${ }^{49}$ Given how hard it is to obtain good results with a production function, these findings are acceptable. The capital share is a bit low, but the estimates of total factor productivity growth are in line with the previous estimates.

Some difficulties were encountered in the empirical application, however. One is that in manufacturing the 1968-73 period showed rapid growth of total factor productivity, no matter how it was calculated. This is caused by the growth in 1971-72 and 1972-73. These were years greatly altered by the 1980 data revision, and probably were years in which the true price index was very uncertain. The $1971-73$ period was also one of very strong demand in manufacturing, so part of the strong

49. For nonfinancial corporations and manufacturing this constraint is not rejected by the data when it is removed. For the nonfarm business sector the unconstrained data show diminishing returns to scale. The expected signs and significance of the coefficients remain when the constraint is removed in all cases. Because of the constraint, the $t$-statistics on $\Delta \ln L$ and $\Delta \ln C K$ are not independent. For example, in the equation for nonfinancial corporations the $t$-statistic 13.0 is for the hypothesis $\alpha>0$. The $t$-statistic 4.0 is for the hypothesis $\alpha<1$, where $\alpha$ is the parameter describing labor's share. 
productivity growth may be simply cyclical. But there is a puzzle here. A second and perhaps related difficulty may arise because the speculative boom in the stock market brought an escalation of real market value in the mid-1960s in both manufacturing corporations and nonfinancial corporations as a whole. If there were a way to smooth that boom that was not simply arbitrary manipulation of the data, market value could be used to track post-1948 productivity trends very closely.

These difficulties notwithstanding, the empirical application of the model gives results consistent with the capital services explanation of the recent slowdown of productivity growth.

\section{Productivity at the Sectoral Level}

When evaluating hypotheses about the productivity growth slowdown it is natural to ask how they pertain to the various sectors; but there are serious problems of measurement and interpretation in doing this. First, information about the allocation of resources to one sector or another is imperfect and may get worse over time as firms merge and new firms form. Edward Denison has consistently argued that it is better to measure output and productivity at the level of nonfinancial corporations or the business sector than at a more disaggregated level such as manufacturing because of the severe problems in allocating real value-added among sectors.

Second, even if the available data on sectoral productivity are accepted, there are conceptual problems in relating them to the aggregates. Suppose an industry is faced with a sudden increase in foreign competition and half of the domestic plants are closed down and the capital goods scrapped. If only the most efficient plants remain, labor productivity in this industry could well increase. For the economy as a whole, however, the effective capital stock has been reduced. If a U.S. industry reacts differently to the increase in foreign competition, the story may be different. If it responds to the fall in demand for its domestically produced product as it does to a business cycle downturn, it may experience at least a temporary downturn in labor productivity. ${ }^{50}$ At the sectoral level,

50. The difficulty of interpretation is highlighted by cross-country comparisons. Data from the Organisation for Economic Co-operation and Development that compare two-digit manufacturing sectors for four major countries reveal virtually 
moreover, rates of technical change will be more variable than in the aggregate. If some industry has done well in the 1970 s even though it is energy-intensive, it presumably would have done even better without the energy crisis. ${ }^{51}$

Despite these potential pitfalls, some observations from individual industries and sectoral shifts do fit with the modeling in this paper. As mentioned earlier, employment has shifted from the industrial sector to services and wholesale and retail trade. Presumably the industrial sector, and manufacturing in particular, has been affected by energy, foreign trade, and perhaps other structural changes. The resulting decline in capital services has slowed employment growth within the industrial sector and overall growth of real wages in the economy. This has encouraged all sectors to use more labor-intensive techniques of production. In 1968 services and wholesale and retail trade accounted for 44 percent of total private employment. But between 1968 and 1979, 70 percent of the total increase in private sector employment occurred in these three areas. In terms of the model in this paper, these employment shifts may be seen as an important consequence of the economy-wide decline in capital services. The decline in productivity in construction may also have resulted in part from the effect of employment mix. This industry once employed largely high-skilled union workers; now it is predominantly nonunion, and its members are relatively unskilled laborers. ${ }^{52}$

The electricity-generating industry is highly capital intensive and has been greatly affected by the rise in the price of energy-resulting in a substantial decline in the flow of capital services relative to the available capital stock. A drop in the overall utilization rate of the capital, rather

no correlation in industry productivity behavior. See $O E C D$, Economic Outlook, July 1979 (Paris: OECD, 1979), p. 35. This is despite the fact that all the countries experienced a slowdown. The energy crisis, shifting trade patterns, and regulation all were felt in these countries, but their impact varied greatly depending on particular economic conditions and the responses of the firms in the different countries. These data need further investigation. But at the very least, they caution against simply looking at different sectors to decide whether energy or some other explanation of the slowdown is correct.

51. It is also important to realize that there is no monotonic relation in the cross section between productivity growth and average $q$. In fact, sectors with high rates of embodied technical change will have persistently low $q$ because the old capital becomes obsolete so quickly; the electronics industries are an example.

52. Julian E. Lange and Daniel Quinn Mills, The Construction Industry (Lexington Books, 1979). 
than shifts across vintages or increased scrapping, has been the principal cause of the decline in services, although some obsolete plants have been retired. The experience of the industry has been described by Andrew Carron and Paul MacAvoy. ${ }^{53}$ Annual output growth for electric utilities averaged 7.1 percent in $1965-69,6.3$ percent in $1969-73$ and -0.3 percent in 1973-77.54 This decline in output growth was paralleled by a slowdown in productivity growth. Labor productivity rose by 4.9 percent a year in 1965-69, 3.9 percent a year in 1969-73, and stopped growing after 1973. Carron and MacAvoy argue: "One cause of this reduction in productivity was the lower rate of utilization of capacity, particularly new capacity, consequent from the economy-wide slowdown of demand growth. The capital-intensive regulated industries, which plan investment far in advance ... ., were not able to adjust rapidly to a lower level of final demand growth."

The capability margin for utilities provides a measure of utilization. This is the margin of reserve generating capacity relative to the peak demand period during the year. This margin was 31.0 percent in 1961 . It fell to 22.9 percent in 1965 and to 16.6 percent by 1969 . These increases of demand relative to capacity were important factors in the rapid growth of labor productivity. In 1969 there were "brownouts" and other signs of capacity shortage, and the margin was increased to 20.8 percent by 1973 . By 1979 this margin was 36.1 percent or almost 20 percentage points above its 1969 low point, which represents a very substantial drop in capital services relative to the stock.

Productivity is affected by the utilization of the transmission and distribution system as well as by the utilization of generating capacity. ${ }^{55}$ Productivity gains in this sector have been achieved, in part, almost automatically as the demand for electricity per household or per establishment has risen. This increase has allowed more output to be pumped through a given distribution network. Once demand per household or establishment starts to decline, as it did after 1973 , so does productivity from this source.

53. Andrew S. Carron and Paul W. MacAvoy, The Decline of Service in Regulated Industries (American Enterprise Institute, 1981). All data in this section on electric utilities are taken from this source.

54. Ibid., p. 40.

55. This point has been made by Thurow in "The Productivity Problem." 
The airline industry has also been greatly affected by the rise in the price of energy. In this industry the vintage capital framework, retrofitting, and scrapping are all important. Economic obsolescence determines when planes are retired. According to a recent newspaper article, "Ordinarily you shouldn't have to replace a plane ... aircraft don't wear out. ... If a part shows signs of stress you merely replace it. . . The real issues are ... route changes ... [that] can alter the kind of fleet a carrier will need. Soaring fuel prices [that] have made gas guzzling 707's and DC 8's uneconomical. And new smoke-and-noise-abatement standards [that] are threatening to make some planes obsolete." ${ }_{56}$

Because of this obsolescence old planes are being retired. Another newspaper stated "Airlines such as Trans World, Pan Am and American are ... retiring their fleets at a rate of some 20 jets a year." ${ }^{57}$ The Civil Aeronautics Board reports that 312 "old large" aircraft were retired from use in the 1970-79 period, leaving only 184 in service in $1979 .{ }^{58}$ The market value of these obsolete planes is low indeed. Following the 1979 energy price increase, many old aircraft are being modified. The same newspaper reported "Owners of the super-60 series of the DC $8 \ldots$ are sending them in for 'retrofitting,' a process of installing efficient, quieter engines at a cost of about $\$ 15$ million a plane." ${ }_{59}$ Other planes, such as the Boeing 727 , are also being retrofitted.

Although the airline industry is a classic example of the process modeled in this paper, labor productivity growth has been affected by a variety of factors of which the retirement of capital is only one. The annual increase in labor productivity averaged 7.0 percent in 1954-68, 4.6 percent in 1968-73, and 4.9 percent in $1973-78 .{ }^{60}$ Without capital obsolescence, one would have expected rapid productivity growth in this industry in the late 1970s. In this period the deregulation of airlines raised

56. Art Pine, "Aircraft Resale: Previously Owned 747-For You a Special Deal," The Washington Post, March 22, 1981.

57. Bruce Hager, "New Life for Old Jets in Engine Jobs," New York Times, April 19, 1981.

58. These figures, from various issues of the Civil Aeronautics Board's Aircraft Operating Cost and Performance Report, were called to my attention by Robert $\mathrm{J}$. Gordon.

59. New York Times, April 19, 1981.

60. Bureau of Labor Statistics Productivity Indexes, p. 169. 
load factors, ${ }^{61}$ favored the more efficient carriers, and reduced the offering of additional service as a means of competing for passengers.

The mining sector of the economy has experienced a sharp decline in productivity because the natural resource base in oil and gas has been declining and the rise in the price of energy has induced a substantial increase in the amount of capital and labor applied to this diminishing resource base. ${ }^{62}$ The slowdown in productivity in mining, therefore, is not a great mystery. If the available natural resource base is viewed as a capital good whose services have been diminishing, productivity developments in this industry do fit the model.

This brief review of a few sectors represents only a sketch of work that would be necessary to determine the importance of the decline in capital services and of energy, foreign trade, regulation, and product market shifts in explaining sectoral productivity behavior. Special developments abound, and these will not fit neatly into any simple model. Nonetheless, it appears that some sectors do reveal the kinds of behavior modeled here.

\section{Conclusions and Implications for Investment}

This paper argues that the slowdown in labor productivity growth that has occurred since 1968 and particularly since 1973 has probably been caused by a decline in the services of capital and labor relative to the measured quantities of these inputs. There is enough suggestive evidence of a decrease in effective labor input relative to measured labor hours to attribute about one-seventh of the productivity growth decline to this source. These effects have been concentrated outside the main manufacturing and industrial sectors.

The most important cause of the growth slowdown in recent years seems to be a decline in the services of capital, caused by obsolescence and by the diversion of some part of capital spending to saving energy or product conversion. The drop in the market value of capital, shown by

61. Between 1973 and 1979 the average load factor increased 20 percent, and seating density increased 7 percent according to Carron and MacAvoy, "The Decline of Service," p. 61.

62. See William D. Nordhaus, "Oil and Economic Performance in Industrial Countries," $B P E A, 2: 1980$, pp. 341-88, for a discussion of this sector. Labor relations difficulties have plagued coal mining, and the mine safety act has also been important. But oil and gas dominate the overall mining series. 
the decline in Tobin's $q$, provides a signal that capital services have decreased. Obsolescence reduces profit net of economic depreciation sharply, a development that should show up in a reduced $q$, while gross profit remains strong. It is possible that the decline in $q$ has not signaled a decline in capital services, but rather has come about from other, unknown causes. But there have been three major puzzles in the 1970s. Why has $q$ fallen? Why has investment remained strong given the low $q$ ? Why has productivity declined? A decline in capital services links these puzzles together and makes them all easier to understand. It would be a remarkable coincidence if, in fact, they are independent with unrelated explanations.

A decline in capital services relative to the capital stock of 2 percent a year in 1968-78 is sufficient to explain the productivity slowdown. This paper argues that structural change in the economy, in part in response to higher energy prices, has been the underlying cause of the increased rate of capital obsolescence. During the 1950s and 1960s the index of capital services developed here rose relative to the measured capital stock, probably because the economy emerged from World War II with a capital stock that needed to be rebuilt. According to the model in this paper, this means conventional estimates based on the measured capital stock overstated the rate of total factor productivity growth through the mid-1960s, and the steady-state productivity growth rate of the U.S. economy is lower than has been thought. Thus some part of the recent productivity slowdown is simply a return to the long-run steady-state path.

An implication of this paper is that investment may do more to improve productivity growth than a conventional analysis predicts. The basic arithmetic of growth analysis suggests that adding 1 percentage point to the growth rate of the capital stock adds 0.25 percentage point to the growth rate of output and productivity. In this model, however, the amount of additional investment that would add 1 point to the growth rate of the capital stock is enough to add $K / V$ points to capital services. ${ }^{63}$ If the ratio of capital services to capital stock were $0.6, K / V$ would be 1.67 , so adding 1 percentage point to the growth rate of the capital stock would add 0.42 point to output and productivity growth. ${ }^{64}$

63. This is because the measure of capital services, $V$, has a growth rate depending upon $I / V$, whereas the capital stock, $K$, has a growth rate depending upon $I / K$.

64. Actual market value would correctly measure capital services if the equilibrium value of Tobin's average $q$ were equal to 0.6 . 
There is an important qualification to this conclusion. If major structural changes are expected to continue into the 1980s and no one is certain what they will be, making large-scale capital commitments today becomes risky. The decline in capital services in the 1970s came about because of a high rate of economic depreciation. We will gain little by adding substantially to the growth rate of gross output if we add little to output net of economic depreciation. The payoff to investment will be exceptionally large provided that new capital can avoid the problem of obsolescence that slowed productivity during the past decade. 


\section{Comments and Discussion}

Robert J. Gordon: Martin Baily's analysis of the U.S. productivity growth slowdown is important and original. Unlike the studies of Denison and others, it concludes that the slowdown can be explained within the framework of conventional economic analysis and does not have to be relegated to the status of an unsolved mystery. Unlike the papers by Rasche and Tatom, it proposes a channel by which higher energy prices could have explained much of the puzzle, rather than simply resting its case on an observed time-series correlation between energy prices and productivity behavior. ${ }^{1}$

In Baily's analysis, energy prices are a major, but not the only, source of a reduction in capital services that explains the productivity slowdown. If his capital effectiveness hypothesis is accepted, Baily's paper will have wide-ranging implications for economic forecasting and policy. Among these are that the productivity growth slowdown is temporary, that productivity growth will eventually resume in the absence of future oil shocks, and that incentives for saving and investment are warranted to stimulate the replacement of prematurely obsolete old capital by new capital designed for the new processes and products appropriate in a regime of higher energy prices.

A novice detective newly assigned to investigate the productivity mystery would be immediately impressed by the trail of circumstantial evidence leading to energy prices as the prime suspect-most of the slow-

1. Robert A. Rasche and John A. Tatom, "Energy Price Shocks, Aggregate Supply, and Monetary Policy: The Theory and the International Evidence," in Karl Brunner and Allen H. Metzler, eds., Supply Shocks, Incentives, and National Wealth, Carnegie-Rochester Conference Series on Public Policy, vol. 14 (Amsterdam: North-Holland, 1981), pp. 9-93. 
down occurred after the initial 1973 OPEC shock; an even more ominous absolute decline in the level of U.S. productivity has occurred in the wake of the 1979-80 OPEC shock; and productivity growth simultaneously fell in most industrial countries after 1973, just when these countries were exposed to the common influence of higher oil prices. However, the novice detective is likely to find, upon announcement that he has a prime suspect, that the older detectives on the force yawn with boredom and tell him to look elsewhere with "Don't you know that the 5 percent share of energy usage in GNP, multiplied by the 2 percentage point slowdown in the growth of the energy-to-GNP ratio, can only explain 0.1 point of the total 2.0 point productivity slowdown? This leaves 1.9 points to be explained by other suspects." Slightly discouraged, the novice asks his senior colleagues whom they have found as a prime suspect and is surprised to find that their response consists only of prolonged silence.

Baily's paper can be viewed as an outgrowth of the earlier hypothesis of Berndt-Wood and Hudson-Jorgenson that, because capital and energy are complements, higher energy prices should cause a substitution from capital to labor. Opponents of this hypothesis have pointed to the inability of the observed behavior of the capital stock data to explain much of the productivity slowdown when fed through the conventional arithmetic of growth accounting. But, as Baily points out, official data on the capital stock are created by the perpetual inventory method with fixed retirement and depreciation patterns. By design, these data are incapable of capturing the effects of higher energy prices in both raising the rate of obsolescence and premature retirement and in causing lower utilization rates. Because output is produced by capital services, not a mechanically measured capital stock, it is plausible that the growth rate of capital services has declined by enough to explain most or all of the productivity slowdown.

This idea has been suggested before (for example, when Rasche and Tatom refer to premature capital retirement as an explanation of their enormous coefficients on the relative price of energy in productivity equations), but Baily's paper contains several original ideas, which, at least as far as I know, have not previously been fully developed or tied together. First, the energy price impact can show up not just in premature scrappage, but may primarily take the form of reduced utilization. Second, premature obsolescence not only changes the ratio of effective to measured capital, but also changes the ratio of true profits to measured 
profits, since depreciation deductions are understated when economic lifetimes suddenly shrink. This disguised decline in profitability, in turn, may have been recognized by efficient financial markets and may constitute a more satisfactory explanation of the low level of stock market prices in the past decade than the alternative hypothesis of investor irrationality. Baily's demonstration that the efficient-markets valuation of a firm mirrors effective capital input in a vintage model seems convincing given his assumptions, and the correlation between market value and effective capital should survive in a more general dynamic model, as he suggests in his discussion of putty-clay.

But proposing the effective capital hypothesis is not the same as providing a convincing empirical validation. Baily's evidence in table 6 amounts to little more than a restatement that the stock market and productivity puzzles occurred simultaneously. The slowdown in productivity growth can be "explained" when a conventional index of capital input is replaced by one that consists of a two-thirds weight on conventional capital and one-third on an index of stock market value. To go beyond this, and to convince skeptics, Baily or his future disciples will have to measure effective capital directly and produce numbers that are consistent with table 6, which implies that the ratio of effective to measured capital fell cumulatively by almost 20 percent between 1968 and 1978, as shown below.

\begin{tabular}{|c|c|c|c|c|}
\hline \multirow{2}{*}{ Equipment and structures } & 1948 & 1968 & 1973 & 1978 \\
\hline & & & & \\
\hline$(1948=100)$ & 100.0 & 217.3 & 267.5 & 313.0 \\
\hline Combined capital index & & & & \\
\hline$(1948=100)$ & 100.0 & 252.9 & 295.4 & 295.4 \\
\hline $\begin{array}{l}\text { Ratio of combined capital } \\
\text { index to equipment and } \\
\text { structures }\end{array}$ & 1.000 & 1.164 & 1.104 & 0.944 \\
\hline
\end{tabular}

This estimate of a 20 percent required drop in the ratio of effective to actual capital corresponds fairly closely to an estimate I made from Rasche and Tatom's energy price coefficients that premature retirement of 28 percent of the U.S. capital stock would have been necessary to rationalize their results. ${ }^{2}$

2. Robert J. Gordon, "Comment on R. Rasche and J. Tatom, 'Energy Price Shocks, Aggregate Supply, and Monetary Policy: The Theory and the International Evidence,'” in Brunner and Metzler, eds., Supply Shocks, p. 98. 
Is there any evidence available to support Baily's conjectures? His own disaggregations make this look difficult. Baily's table 2 shows that the slowdown in the nonfarm nonmanufacturing sector between the 1957-68 and 1973-79 periods was almost double the size of the slowdown in manufacturing, and over half of that slowdown occurred before 1973. These figures exacerbate the task of proving Baily's hypothesis-first, because data limitations and conceptual difficulties prevent the construction of a capital utilization series for most sectors within nonfarm nonmanufacturing and, second, because the large fraction of the slowdown in the productivity of that sector before 1973 casts suspicion on energy prices as the prime suspect. Yet, to convince skeptics, Baily must somehow show that effective capital utilization has declined in those parts of the economy in which measuring utilization is difficult, if not impossible.

Baily's model with heterogeneous capital requires that the events of the 1970s appear as a decline in the utilization of old plants and machines relative to new ones. Yet my own preliminary investigation of two industries that Baily cites as favorable to his hypothesis-electric generating plants and airlines-does not produce the required pattern of utilization changes. The electric utility industry provides a classic case study of a slowdown in productivity growth, with steady deceleration of productivity improvement in the period between 1948 and 1973, followed by a disappearance of productivity growth altogether after 1973.

A nıore precisely focused view of the electric generating industry is provided in table 1, which exhibits data on utilization rates and productivity for a large sample of nonnuclear generating plants. The average rates of productivity growth for all plants over the five intervals in the table are, respectively, $8.01,8.66,6.59,1.35$, and 1.31 percent a year, indicating a drastic slowdown in growth that preceded the 1973 OPEC oil shock. It is clear that Baily's model provides little help in explaining this phenomenon. The utilization rate for all plants dropped only from 51.5 to 49.2 percent between $1958-59$ and 1977. A more interesting result appears in the ratio of the utilization rate of new plants to that of all plants, which shows a decline from 126 to 77 percent over the same interval. I do not have a full explanation for this phenomenon, but it is neither consistent with nor explained by Baily's vintage model. Two factors may have been at work - the increasing size of plants, which allowed operating economies, ceased in the mid-1960s, and environmental legislation may actually have made new plants less efficient than old plants (but the 
Table 1. Utilization Rates and Productivity for a Sample of Nonnuclear Electric Generating Plants, Selected Periods, 1948-77

\begin{tabular}{lcccccc}
\hline \multicolumn{1}{c}{ Item } & $1948-49$ & $1958-59$ & $1963-64$ & $1968-69$ & $1971-72$ & 1977 \\
\hline $\begin{array}{l}\text { Utilization rate (percent) } \\
\quad \text { New plants }\end{array}$ & 61.8 & 64.9 & 60.3 & 52.5 & 47.3 & 38.1 \\
$\begin{array}{l}\text { All plants } \\
\text { Ratio of new to all }\end{array}$ & 60.7 & 51.5 & 52.8 & 56.5 & 56.5 & 49.2 \\
$\quad$ plants & 1.02 & 1.26 & 1.14 & 0.93 & 0.84 & 0.77 \\
$\begin{array}{l}\text { Output per employee } \\
\quad \text { (million kilowatt- }\end{array}$ & & & & & & \\
$\quad$ hours per employee) & & & & & & \\
$\quad \begin{array}{l}\text { New plants } \\
\text { All plants }\end{array}$ & 8.95 & 19.77 & 31.43 & 33.99 & 35.86 & $24.63^{\mathrm{b}}$ \\
\hline
\end{tabular}

Source: Data for 1948-72 were provided by T. G. Cowing of the Economic Growth Institute, State University of New York at Binghamton, based on a sample of plant data reported in Energy Information Administration, Steam-Electric Plant Construction Cost and Annual Production Expenses, various issues. New plant data for 1971-72 and all data in 1977 are from a sample recorded in Steam Electric Plant Construction Cost and Annual Production Expenses, 1971, 1972, 1976, 1977, with plants chosen for the same firms as in the 1948-72 sample.

a. New plant data are reported for the first full year of operation in each period.

b. New plant data are based on an average of 1976 and 1977 observations to increase the sample size.

legislation should apply equally to all plants). Overall, Nordhaus' hypothesis of an exogenous and unexplained reduction in the rate of technical improvement is likely to come out ahead in explaining the electric utility growth slowdown. ${ }^{3}$

In the airline industry, which has perhaps been more severely affected by higher energy prices than any other, there is no evidence of the mechanism that Baily proposes. First, there was no slowdown in productivity growth after the first 1973 oil shock. The annual growth of output per man-hour in the industry was, in Baily's paper, 4.6 percent a year between 1968 and 1973, and 4.9 percent a year between 1973 and 1979. The airlines appear to have reacted to the financial squeeze of higher oil prices to move closer to an "efficiency frontier"-unprofitable routes were dropped, more and narrower seats were added to wide-body aircraft, and the percentage of seats occupied was raised.

Was there a shift toward premature retirement and lower utilization of older units of capital in the case of airlines? Table 2 provides information on three general types of jet aircraft, a "new large" category (747, DC10,

3. William D. Nordhaus, "Policy Responses to the Productivity Slowdown," in Federal Reserve Bank of Boston, The Decline in Productivity Growth, Conference Series 22 (FRBB, 1980), pp. 147-72. 
Table 2. Characteristics of Domestic Trunk Airline Operations, 1970-79

\begin{tabular}{cccccccc}
\hline & \multicolumn{3}{c}{ Number of aircraft } & in service & & \multicolumn{3}{c}{ Utilization (hours per day) } \\
\cline { 2 - 3 } \cline { 6 - 7 } Year & $\begin{array}{c}\text { New } \\
\text { large }\end{array}$ & $\begin{array}{c}\text { Old } \\
\text { large }\end{array}$ & Small & & $\begin{array}{c}\text { New } \\
\text { large }\end{array}$ & $\begin{array}{c}\text { Old } \\
\text { large }\end{array}$ & Small \\
\hline 1970 & 13 & 496 & 892 & & 8.5 & 8.4 & 6.8 \\
1971 & 45 & 462 & 906 & & 8.9 & 8.1 & 6.9 \\
1972 & 88 & 422 & 896 & & 8.5 & 8.0 & 6.9 \\
1973 & 137 & 366 & 894 & & 8.8 & 7.8 & 7.3 \\
1974 & 178 & 288 & 928 & & 7.8 & 7.6 & 6.9 \\
1975 & 200 & 277 & 932 & & 7.7 & 7.2 & 6.9 \\
1976 & 222 & 259 & 975 & & 7.7 & 7.2 & 7.1 \\
1977 & 222 & 239 & 1,006 & & 8.2 & 7.4 & 7.3 \\
1978 & 222 & 202 & 1,040 & & 8.4 & 7.7 & 7.5 \\
1979 & 206 & 184 & 1,054 & & 8.9 & 8.1 & 8.1 \\
\hline
\end{tabular}

Sources: U.S. Civil Aeronautics Board, Aircraft Operating Cost and Performance Report, July 1980 and preceding issues.

L1011), an "old large" category (707, DC8), and a "small" category $(727,737$, DC9). The major episode of retirement of old large aircraft came in 1972-74, but this seems to be better explained by the production schedule of new large aircraft than by the timing of the 1973 OPEC shock. There seems to have been little change in utilization rates between 1971 and 1979, with old planes averaging about 0.6 hour a day less utilization. In fact, the major shift seems to have been an increase after 1975 in the use of small planes, most of which had been built before 1970.

Some of the productivity slowdown in the nonfarm nonmanufacturing sector may be an indirect consequence of the slower growth in output since 1973. Along the lines suggested by Baily, some of the newly built shopping centers of the 1970s may have been utilized much less than expected, due both to slower growth in real consumption and also to the incentive of higher energy prices to compress the dimensions of each metropolitan area. The juxtaposition of the examples-the electric generating industry, the airline industry, and shopping centers-points out an important qualification to Baily's theoretical analysis. A vintage model with heterogeneous capital is sufficient but not necessary to result in variations in the ratio of effective to conventionally measured capital. Even with homogeneous capital, higher energy prices could lead to a reduction in utilization. In fact, it is the oldest capital that has been 
"grounded" in the airline case, but the newest capital in the electricity and shopping center examples.

The ultimate verdict on Baily's hypothesis will depend on the outcome of careful exercises in the measurement of capital services and of output itself. Baily's paper stresses the dislocation to the automobile industry caused by the need to spend tens of billions of dollars retooling to produce more energy-efficient output. The retooling effort involves prematurely throwing out existing equipment and plant, thus causing conventional measures to overstate capital input. Perhaps as important is that the government has no procedures by which a shift in product development from large gas guzzlers to small, fuel-efficient automobiles can be properly treated by price indexes like the consumer price index, and hence by official output measures. In one case study, I developed new price indexes for commercial aircraft that took full account of the value to users of improved operating efficiency. Primarily because of the introduction of jet aircraft, the estimated annual growth in output and productivity was increased sharply by this quality adjustment. Similar studies to quantify the user value of energy savings in the automobile, appliance, and other industries may ultimately explain part of the productivity puzzle.

Another area of mismeasurement related to the productivity slowdown has occurred in an industry that has been relatively untouched by higher energy prices-electronics and office equipment. It has long been official government policy to ignore the declining price of electronic computers and related equipment, and this has led to a growing understatement of output growth in this branch of manufacturing. Further, there may be a more subtle channel by which the electronic revolution has caused an understatement of output growth in the nonfarm nonmanufacturing sector. A large part of the electronic equipment purchased by the financial sector has been designed to change the nature of services available to consumers-for example, twenty-four hour money machines and more detailed bank statements. Improved computers to arrange airline reservations and seat selection systems are in the same category. Because the improvements in the nature of output are not counted in the GNP and productivity data, I suspect that a growing part of investment may have a marginal product that is officially measured to be zero but is socially evaluated to be positive. 
To conclude, I find Baily's basic idea persuasive, but suspect that it will be hard to validate directly.

Robert M. Solow: I am told that the early line in Las Vegas was three to one against Baily, or anyone else, coming up with something new to say about the productivity slowdown at this late date. If I were a betting man, I would have gone with the odds. As usual, I would have been wrong. That is why I am not a betting man. Besides a number of intelligent side comments, Martin Baily's paper contains two interesting, original, and enlightening ideas, one of which comes out negative and the other positive. I concentrate on them.

First, however, I would like to make a cautionary remark about the very nature of the exercise. A productivity puzzle is said to exist when all the measurable causal factors that can be mustered are only able to account for a fraction, say half, of the observed deceleration in labor productivity. The rest is left as an unexplained deceleration of the growth of the residual. To solve the productivity puzzle is to explain in some other way that remaining half of the deceleration. So the puzzle is completely solved when the claim can be made that the growth rate of the residual did not change in the 1970s after all. So far as I know, there is no reason to believe that the Divine Economist intended the residual to grow at a constant compound interest rate forever. If there were such a doctrine, there would surely already be lawsuits to require that it be taught in the schools. My impression is that the residual moves with some irregularity. Almost the only constant growth rate one could imagine for it is zero: a number growing like a pure exponential could hardly be called a residual, except for the limiting case that there is no residual.

I do not mean to say that economists should stop whittling away at the residual, trying to reduce it, and trying to reduce dependence on variations in its growth rate to explain changes in the productivity trend. Even if growth accounting is unlikely to be so Newtonian as to succeed in eliminating residual growth entirely, the effort has to be made. But I am cynical enough about empirical economics to fear that if we continue at it long enough we will succeed in eliminating the residual, even if it is really there. The enterprise calls for caution and tentativeness and thought, more than number-pushing. That is one reason why I like what Baily has done.

His first major contribution is to throw cold water on the comforting 
notion that they just do not make people the way they used to, the idea that recent additions to the labor force are somehow fundamentally less productive than people of the same age were in earlier cohorts. Baily approaches this problem indirectly. Suppose there were a cohort-specific productivity factor, and suppose it evolved smoothly over successive cohorts, like a fourth-degree polynomial to be specific. Baily calculates what that cohort-specific productivity pattern must be in order for it to give a good representation of aggregate labor quality when all active cohorts are added up with the appropriate empirical weights. The result is given in table 4 of the paper. Baily concludes, and I agree, that the implied answer is implausible. It is really hard to believe that the cohort born in 1963 is intrinsically only about half as productive, on the average, as the cohort born in 1943. But that is what is implied if the drag from the relatively small number of young people is to explain the overall drop in labor quality. The hypothesis cannot carry the weight required of it.

Baily goes on to discuss, in a fragmentary way, the related idea that there has been a general, not cohort-specific, decline in effort per hour nominally worked, or even that actual hours worked have fallen faster than reported hours worked. The time diaries he mentions do provide a snapshot of how workers actually spent their time at work but no evidence on changes in that behavior. I wish there were some way of checking the casual notion that there has been a widespread expansion of on-the-job leisure. Maybe a close study of collective bargaining contracts over a couple of decades would give a partial answer. That sort of change would have the merit of being a natural and even desirable aspect of rising standards of living.

The second and more striking contribution of the paper is a serious reconsideration of the possibility that the measurement of capital input by the net stock at reproduction cost may progressively overstate the flow of capital services in recent years. This part of the paper is both intellectually and practically satisfying. It is neat; and there is an excellent chance that it is really telling us something about the world.

Baily uses a very special model, but there is little doubt that the general idea would carry over to some more general settings. There are two kinds of systematic effects on productivity. One is the standard sort of vintagespecific neutral technological change. It should appropriately be thought of as capital-augmenting in this context. The other is described by Baily 
as a sort of "structural-change-induced obsolescence"; it enters like Hicks-neutral exponential technological decay related to the age of capital rather than its vintage. The story Baily has in mind is that events like the rapid rise in the relative price of energy render some items of capital equipment unexpectedly unsuitable, or require costly retrofitting that can also be modeled as rapid obsolescence. Moreover, industries that produce energy-using items like automobiles or refrigerators may also find that their product has become unsuitable for the new price-configuration; and this too can be summarized loosely as rapid obsolescence of equipment in the automobile or appliance industry. Baily models this sort of event as a speedup in the rate of exponential technological decay. That seems a little strong to me. A once-and-for-all reduction in the level of effective output produced by old capital would be more plausible and would probably have less dramatic consequences. Baily's gambit might be more plausible if it involved a temporary increase in the rate of obsolescence, followed by a return to the original rate, at a permanently lower level. That would leave him with the problem of deciding when the episode was over; it would also entail catch-up effects that have not yet been seen. But perhaps they are still to come.

This vintage model has the perfectly charming property that it admits an aggregate production function with neutral technological change in which the appropriate, the technologically appropriate, measure of the flow of capital services is the forward-looking perfect-foresight market value of the hodge-podge of capital stocks of different vintages. Because of the coexistence of different vintages, with different initial technological levels and different amounts of experienced obsolescence, this forwardlooking market value differs from the reproduction cost of the capital stock, or rather from the amount of output that went into the production of the particular capital items now in existence. So Tobin's $q$ has a natural niche in this model of production.

A foreseen permanent increase in the rate of vintage-specific capitalaugmenting technological progress causes $q$ to fall-that is, decreases the value of the stock of capital goods because it pulls labor away from older capital and diminishes its flow of quasi-rents. An increase in the rate of obsolescence lowers the value of the existing stock for obvious reasons. There is no way of separating those effects. But if the market value of the capital stock is the right variable for growth-accounting, it is obviously 
easier to account for the productivity slowdown. Baily shows that when capital input is measured by real market value there is essentially no remaining deceleration of the residual to worry about. The productivity slowdown was caused by whatever caused $q$ to fall. This is a gross overstatement, and Baily should perhaps be more cautious. The recorded fall in $q$ may have many causes. Only to the extent that it reflects a foreseen drop in previously expected quasi-rents is it relevant to Baily's purpose.

There is a second reason for questioning the direct applicability of this model to the years after 1973. When an adverse shock occurs, there is a simultaneous deceleration of productivity by virtue of the ad hoc obsolescence factor in a putty-putty model. If there is little or no ex post flexibility in the labor requirements for production on already existing capital, as most of us casually believe, the timing must be rather different. When the price of oil rises, current and expected future quasi-rents fall. The anticipated retirement date of existing capital comes closer in time. For both reasons, market value falls instantaneously. The assumption of ex post fixed proportions means, however, that there is no change in recorded productivity on old capital until it is retired. Only as gross investment creates plants whose factor proportions reflect the substitution of labor for energy (and for complementary capital) does the productivity curve decelerate. I do not think this lag can be aggregated away rigorously, but aggregation will certainly smooth the process.

In my view, the Baily idea survives as a genuine insight into one source of the productivity slowdown, even if it cannot be translated literally from this rather special model into the real world.

Baily's candidate for the ultimate cause is structural change, particularly those maladjustments set off by the rise in energy prices. I cannot say that is an unreasonable story. But neither can I say that it is compelling. Presumably every decade has its structural changes and surprises. One tends to think that the oil shock was bigger than most; but then everybody always thinks that "our" shock was bigger than most. I would look for some direct evidence that accelerated obsolescence was a much larger factor in the 1970s than in other periods. Baily does provide some figures showing that the amplitude of changes in relative prices was greater in the 1970s than in the two decades before. It is hard to know what constitutes a big difference in this matter. I was not swept off my feet by the figures, but at least they went in the right direction. Baily has 
opened up a really interesting line of inquiry here; it is quite an achievement. But it badly needs some independent verification, better systematic than anecdotal.

One last point. Baily does not really raise one question that $I$ have occasionally thought is promising. How about the hours of work of capital, another component of the flow of services from a given stock? Murray Foss has recently published some figures showing that plant hours per week rose by 25 percent between 1929 and 1976. ${ }^{1}$ That would suggest a possible underestimate of the growth of the flow of services. But Foss's figures relate only to the endpoints of the long period and tell nothing about shorter-run changes. He has some annual data for manufacturing for 1973-77; they show a sharp cyclical reduction of plant hours per week in the 1974 recession and then a recovery. But 1977 is still 5 percent lower than 1973. That may be too little to matter.

Baily mentions that capital per full-time equivalent worker might be a better measure of capital intensity than capital per hour worked, but then makes no use of it. I think he should have. If weekly hours are proportional to the hours of a full-time worker, capital per hour will overstate capital intensity when the workweek is falling, whereas capital per fulltime equivalent worker will represent it more accurately. But that is a dull point, and Baily's angle is fascinating.

Martin Neil Baily: I have some reservations about Robert Gordon's data on electricity generation and airlines. As a general point, the vintage model predicts less use of the most energy-inefficient capital, but this may not be the oldest. The declining utilization of new versus old generating plants shown in his table 1 is notable; but without further information, it is unexplained by any model, not just mine. It is impressive, and consistent with my model, that labor productivity of the new plants fell abruptly after the energy price increase. Gordon's data on the retirement of "old large" aircraft during the 1970s are consistent with the hypothesis of the paper, while his interesting information on utilization fails to recognize that, within his categories, the mix of aircraft has changed over time. The same source he cites in the table reveals, for example, that the DC8-50 was utilized 7.05 hours a day in 1979 compared with 8.48 hours for the more modern DC8-61 and 8.88 hours for the DC8-62. The DC8-10 and

1. Murray F. Foss, Changes in the Workweek of Fixed Capital: U.S. Manufacturing, 1929 to 1976 (American Enterprise Institute, 1981), pp. 2, 8. 
DC8-30 were the really inefficient versions, but they were phased out completely by 1979 . Similar patterns are shown for the different versions of the 707 and the DC9.

\section{General Discussion}

Baily's hypothesis that declining capital services had contributed to the productivity slowdown seemed plausible to many participants. However, several questioned using $q$ as a way of identifying that decline. One issue was whether events that affected productivity through capital services would be properly measured by $q$. Another was whether $q$ was influenced by developments unrelated to productivity. Jeffrey Sachs observed that, allowing for either putty-clay capital or costs of adjusting the capital stock - both of which he regarded as more realistic assumptions than the putty-putty technology without adjustment costs that Baily's formal model assumed $-q$ could move without signaling a change in capital services. Lawrence Summers added that, to the extent reduced $q$ was supposed to have come from oil prices, the reduction in market values that lowered $q$ must have anticipated the effects of those prices on profitability. But productivity should not be affected by such anticipatory effects and therefore would not be tracked by $q$. Alternatively, if markets did not anticipate, so that $q$ reflected current profitability, oil prices could not account for the observed change in $q$ during the 1970s. William Nordhaus agreed that a vintage model with putty-clay technology was needed to reflect the effects of oil prices on obsolescence. He reported that empirical attempts to do this had found only modest effects on productivity.

The discussion turned to the decline in $q$ that had occurred. Franco Modigliani believed the actual decline in the ratio of market value to earnings after 1973 indicated the market's erroneous use of the nominal interest rate to discount future real income streams. He also noted that the ratio of profits to production costs should have declined according to Baily's hypothesis that capital services had declined, while in fact the ratio had changed little. Baily replied that measured profits would not reflect true profits, which should include the decline in the value of the capital stock and its ability to produce output in the future. But Nordhaus noted that, if the decline in $q$ was due to a rise in the discount rates 
applied to future earnings, it would have no connection with capital services and the productivity slowdown. He recalled that William Brainard, John Shoven, and Laurence Weiss (BPEA, 2:1980) had found that the decline in $q$ could not be explained by changes in present and future cash flows and therefore had to come from changes in discount rates. Baily agreed that part of the decline in $q$ in the 1970s may have been a result of an increase in the discount rate. But he argued that the persistence and severity of the decline in $q$, accompanied by enough investment to increase the usual capital stock measures (particularly in manufacturing), also indicates that obsolescence caused part of the decline.

Several participants discussed Baily's views about obsolescence of the capital stock and how it might affect investment and productivity with putty-clay technology. Charles Schultze noted that structural change need not reduce capital services and productivity in the aggregate. In theory, shifts in relative prices because of demand changes would lead to an increase in some quasi-rents and a decrease in others, with no presumption as to the overall sign. Baily replied that the symmetry between gainers and losers cannot exist if there is not sufficient product-specific capital of the sort for which demand increased, so that there is a net loss of effective capital services. Christopher Sims observed that in the standard putty-clay model, when the energy price increased there would be an incentive to immediately replace equipment that was not energy efficient. But if the capital goods themselves had to be redesigned, investment would be delayed until more energy-efficient equipment was available. He also observed that, since real energy prices had been declining before the oil shock, more recent vintages might be less energy-efficient than earlier ones. Scrapping or underutilization to save on energy might therefore involve capital that is relatively high in labor productivity and technology. Capital use in the utility industry could be an example of this phenomenon. Nordhaus said the observed increase in relative price dispersion, which Baily cited as a reflection of structural change, may instead simply indicate the informational inefficiencies of inflation. $\mathrm{He}$ also noted that, since new regulations often exempted existing capital from compliance, they might lead to the postponement of scrapping, which would weaken Baily's argument that regulations had increased obsolescence.

There were some suggestions for further research. Charles Holt suggested examining the experience of other countries to see if differences in 
the average age of capital stock could explain differences in the response of productivity to energy prices. Schultze reported that there had been a substantial decline in the ratio of government to private capital stock. $\mathrm{He}$ suggested that this decline in public investment, if in forms such as highways that aid private production, might have contributed to the productivity decline. Robert Hall mentioned that much of the investment in the form of retrofitting and other attempts at economizing on energy are actually measured as current expenditures and not investment, thus understating both GNP and the size of the capital stock. He advocated closer examination of particular industry behavior along the lines of Robert Gordon's comments. 